\title{
UM ESTUDO SOBRE AS AÇÕES DOCENTES EM UMA ESCOLA DE 1 CICLO EM PORTUGAL
}

\author{
MARCUS VINICIUS MARTINEZ PIRATELO ${ }^{1}$ \\ ORCID: https://orcid.org/0000-0003-2036-0575 \\ SERGIO DE MELLO ARRUDA ${ }^{2}$ \\ ORCID: https://orcid.org/0000-0002-4149-2182 \\ NILZA MARIA VILHENA NUNES DA COSTA ${ }^{3}$ \\ ORCID: https://orcid.org/0000-0002-1707-9697 \\ MARINEZ MENEGHELLO PASSOS ${ }^{4}$ \\ ORCID: https://orcid.org/0000-0001-8856-5521
}

\begin{abstract}
RESUMO: Este artigo apresenta resultados de um estudo realizado a respeito da ação docente de dois professores em uma escola de $1^{\circ}$ ciclo em Portugal. Os fundamentos metodológicos que conduzem a coleta e a organização dos dados baseiam-se nos procedimentos indicados pela Análise Textual Discursiva (ATD) de Moraes e Galiazzi (2011). As aulas dos professores foram analisadas utilizando-se de uma forma de organização dos dados provenientes de dois instrumentos analíticos distintos: a Matriz do Professor, de Arruda e Passos (2017), e o Quadro intitulado "os objetivos e motivos da ação", de Tardif e Lessard (2008). Foi possível identificar as categorias de ação docente realizadas pelos professores e a frequência dessas categorias de ação. Por meio de uma nova maneira de organizar os dados foi possível concluir que o ambiente de sala de aula e o estilo pedagógico de cada professor podem ser fatores decisivos para as ações desempenhadas em classe.
\end{abstract}

Palavras-chave: Ação docente, Ensino de Ciências e Matemática, Relação com o Saber, Matriz do Professor.

\section{A STUDY ABOUT THE TEACHING ACTIONS IN A SCHOOL OF 1ST CYCLE IN PORTUGAL}

ABSTRACT: This paper presents results of a study about the teaching activity of two teachers in a school of 1 st cycle in Portugal. The methodological foundations that lead to data collection and organization are based on Textual Discursive Analysis (TDA) from Moraes e Galiazzi (2011). The teachers classes were analysed using a way of organizing the data coming two different analytical

\footnotetext{
1 Universidade Estadual de Londrina (UEL). Londrina, PR, Brasil. <mvmpiratelo@yahoo.com.br>

2 Universidade Estadual de Londrina (UEL). Londrina, PR, Brasil. < sergioarruda@uel.br>

3 Universidade de Aveiro. Aveiro, Portugal. <nilzacosta@ua.pt>

${ }^{4}$ Universidade Estadual de Londrina (UEL). Londrina, PR, Brasil. <marinezpassos@uel.br> Educação em Revista|Belo Horizonte|v.36|e222681|2020
} 
instruments: the teacher's Matrix from Arruda e Passos (2017), and the Chart called "the objectives and reasons of action", by Tardif e Lessard (2008). It was possible to identify the categories of teaching activity performed by the teachers analyzed and the frequency of these categories of action. Through a new way of organizing the data it was possible to conclude that the classroom environment and the pedagogical style of each teacher can be decisive factors for the actions performed in class.

Keywords: Teaching Action, Science and Mathematics Teaching, Relationship with the Knowledge, Teacher's Matrix. 


\section{INTRODUÇÃO}

No que diz respeito às pesquisas educacionais, a temática referente à ação docente é vista principalmente sob a perspectiva da prescrição; em outras palavras, o que mais se percebe em pesquisas em que a sala de aula é a principal fonte de coleta de dados, é que a pesquisa educacional prioriza a prescrição sobre o que o professor deve ser ou fazer. Essa argumentação pode ser reforçada considerando a tese de doutorado de Passos (2009), que teve como objeto de estudo a análise da produção bibliográfica constituída por artigos publicados em cinco dos principais periódicos nacionais (da primeira década deste século) da área de Educação Matemática (GEPEM, Bolema, Educação Matemática em Revista, Zetetiké e Educação Matemática em Pesquisa). Passos (2009) constatou que os autores enfatizavam os "deveres" do professor e o que ele precisa "ser". A lista de deveres do professor encontrada pela autora nos artigos analisados é imensa, o que nos chamou a atenção para o fato de que, no caso destas pesquisas, a ação docente foi pensada, enfaticamente, sob o viés da prescrição, ou seja, daquilo que o professor deve ser ou fazer.

Ao invés da prescrição, buscamos realizar neste estudo a descrição e a análise das ações dos professores, enfatizando o que esses sujeitos fizeram, de fato, em sala de aula. Compreendemos que o viés descritivo referente à análise da ação docente é pertinente às pesquisas educacionais, pois tem o objetivo de explicitar o que realmente decorre no ambiente de sala de aula, possibilitando a compreensão a respeito das interações que se dão nessa configuração de ensino e aprendizagem.

Segundo Tardif e Lessard (2008, p.36):

Parece-nos que o primeiro passo a ser dado para analisar o trabalho dos professores é fazer uma crítica resoluta das visões normativas e moralizantes da docência, que se interessam antes de tudo pelo que os professores deveriam ou não fazer, deixando de lado o que eles realmente são e fazem.

Para superar estes pontos de vista moralizantes e normativos sobre a docência, os autores sugerem privilegiar:

[...] mais o estudo do que os docentes fazem e não tanto prescrições a respeito do que deveriam fazer ou não deveriam fazer. Dito de outra forma, [...] a docência pode ser analisada como qualquer outro trabalho humano, ou seja, descrevendo e analisando as atividades materiais e simbólicas dos trabalhadores tais como elas são realizadas nos próprios locais de trabalho (TARDIF; LESSARD, 2008, p.37).

Assim, foi necessário levar a pesquisa para a sala de aula e analisar os atores envolvidos nos processos de ensino e aprendizagem. Neste artigo trazemos os resultados de uma observação em que acompanhamos e gravamos dois professores em sala de aula em duas turmas distintas de alunos, com idade de oito a dez anos, em uma escola em Portugal. Dessa forma, a busca pela ênfase na descrição e na análise do que, de fato, ocorria em sala de aula, conduziu-nos à questão que aqui pretendemos responder: Quais as categorias de ação docente identificadas nas aulas de dois professores da escola portuguesa pesquisada?

A seguir, trazemos esclarecimentos a respeito dos instrumentos que nos auxiliaram neste movimento de pesquisa.

\section{INSTRUMENTOS PARA A ANÁLISE DA AÇÃO DOCENTE}

Uma solução para responder à questão de pesquisa enunciada anteriormente foi buscar instrumentos que nos auxiliassem a compreender o que de fato os professores faziam em sala de aula; em outras palavras, precisávamos de instrumentos que nos permitissem elaborar categorias para as ações docentes. Encontramos tais instrumentos no Quadro sobre os objetivos e motivos da ação de Tardif e Lessard (2008) ${ }^{5}$ e na Matriz do Professor - M (P) - de Arruda e Passos (2017). O primeiro instrumento forneceu-nos ideias iniciais para a composição das categorias de ação docente e permitiu

\footnotetext{
${ }^{5}$ Os objetivos e motivos da ação também foram explorados na tese desenvolvida por Piratelo (2018). Neste artigo, priorizamos apenas as categorias de ação docente provenientes da coluna da natureza da ação do Quadro de Tardif e Lessard (2008).
} 
que elaborássemos uma nova forma de organizar os dados, e o segundo foi de fundamental importância para a interpretação dos dados obtidos. Ambos contribuíram para a consolidação dos resultados que pudemos evidenciar desse nosso estudo.

No Quadro dos objetivos e motivos da ação, de Tardif e Lessard (2008, p.237), os autores mostram um exemplo de análise que leva em consideração as ações realizadas por um professor em sala de aula e seus objetivos e motivos. Apresentamos o Quadro 1 a seguir, a título de esclarecimento para o leitor.

QUADRO 1 - Os objetivos e motivos da ação

\begin{tabular}{|c|c|c|}
\hline Natureza da ação & $\begin{array}{l}\text { As atividades em classe } \\
\text { (segmentos tirados do extrato } \\
\text { precedente) }\end{array}$ & Objetivo ou motivo da ação \\
\hline Ordem ao grupo & Vamos sentar. & $\begin{array}{l}\text { Instaurar uma ordem coletiva para a } \\
\text { aprendizagem }\end{array}$ \\
\hline Questão para o grupo & $\begin{array}{l}\text { Alguém já terminou os exercícios de } \\
\text { matemática? }\end{array}$ & $\begin{array}{l}\text { Questão fatual para obter uma } \\
\text { informação }\end{array}$ \\
\hline Ordem para o grupo & $\begin{array}{l}\text { Vamos terminar os exercícios de } \\
\text { matemática. }\end{array}$ & Chamar para o início da tarefa coletiva \\
\hline Chamada à ordem & "Ester, pare de conversar." & Disciplinar uma aluna \\
\hline Supervisão dos exercícios e correção & $\begin{array}{l}\text { Ela caminha entre as carteiras e olha } \\
\text { os exercícios que os alunos fazem. } \\
\text { Corrige e faz comentários. }\end{array}$ & $\begin{array}{l}\text { Trabalho de aprendizagem sob a } \\
\text { supervisão da professora que faz } \\
\text { correções }\end{array}$ \\
\hline Pergunta & $\begin{array}{l}\text { "Silvano, pode fechar a porta, por } \\
\text { favor?" }\end{array}$ & $\begin{array}{l}\text { Eliminar uma situação perturbadora (a } \\
\text { porta aberta) }\end{array}$ \\
\hline Chamada à ordem & $\begin{array}{l}\text { "Samuel, você está demorando muito. } \\
\text { Todo mundo já terminou, menos } \\
\text { você." }\end{array}$ & Disciplinar um aluno \\
\hline Questão para o grupo & $\begin{array}{l}\text { "Quem sabe onde fica a biblioteca?" } \\
\text { (ninguém responde) }\end{array}$ & Questão fatual para obter informação \\
\hline
\end{tabular}

Fonte: Tardif e Lessard (2008, p.237)

Nesse Quadro 1, podemos encontrar, na coluna da "Natureza da ação", uma forma de categorizar as ações docentes desempenhadas em sala de aula. $\mathrm{Na}$ segunda coluna do Quadro, intitulada "As atividades em classe (segmentos tirados do extrato precedente ${ }^{6}$ )" encontram-se os fatos que se sucederam em sala e que foram transcritos para o Quadro. Na coluna "Objetivo ou motivo da ação" encontram-se inferências dos autores acerca dos objetivos ou motivos dos professores para terem desempenhado tais ações. Para as análises desenvolvidas durante a investigação que realizamos e cujos resultados apresentamos neste artigo, não utilizamos a terceira coluna ${ }^{7}$.

$\mathrm{Na}$ obra de Tardif e Lessard (2008) poucos são os trechos de aula analisados por meio desse Quadro, o que nos levou a elaborar diversas outras categorias para as ações observadas nas aulas de dois professores e dois monitores dos laboratórios, o que totalizou 78 tipos de categorias emergentes. Para o presente artigo, como tratamos apenas das ações dos professores, encontramos 47 categorias distintas.

Entretanto, para complementar as análises realizadas, necessitávamos de um instrumento capaz de atribuir caráter não somente descritivo, mas interpretativo às categorias de ação docente emergentes das situações observadas. E, no artigo intitulado "Um novo instrumento para a análise da

\footnotetext{
${ }^{6} \mathrm{O}$ extrato precedente, citado por Tardif e Lessard (2008) na segunda coluna do Quadro 1, diz respeito a uma transcrição de parte de uma aula de um professor, citada pelos autores anteriormente à apresentação de seu quadro intitulado "os objetivos e motivos da ação". Após a apresentação do extrato da aula, os autores buscaram, por meio do quadro, caracterizar as ações deste professor atribuindo a elas objetivos ou motivos.

${ }^{7}$ A terceira coluna do Quadro 1 foi utilizada em Piratelo (2018) para a elaboração de 50 categorias de objetivos e motivos da ação dos professores e monitores, sujeitos de pesquisa. 
ação do professor em sala de aula", de Arruda, Lima e Passos (2011), encontramos fundamento teórico-metodológico para desenvolver as análises pretendidas.

A partir das ideias concebidas por diversos autores como Tardif (2002), Chevallard (2005), Gauthier et al. (2006), Charlot (2000), dentre outros, Arruda, Lima e Passos (2011) elaboraram esse instrumento, cujo objetivo principal era o de analisar as ações dos professores em sala de aula ${ }^{8}$. Atualmente, tal instrumento tem sido chamado por Arruda e Passos (2017) de Matriz do Professor (ou também denominada $\mathrm{M}(\mathrm{P})$ ), visto que, de 2011 até os dias atuais, o instrumento sofreu algumas alterações, principalmente pelo fato de também ter sido utilizado para analisar ações discentes (Matriz do Estudante ou M(E)) e currículos (Matriz do Saber ou M(S)).

Apresentamos então, no Quadro 2, na sequência, a Matriz do Professor desenvolvida por Arruda e Passos (2017, p.105).

QUADRO 2 - Matriz do Professor

\begin{tabular}{|c|c|c|c|}
\hline $\begin{array}{l}\text { Relação com o saber em } \\
\text { sala de aula (Professor) }\end{array}$ & $\begin{array}{c}1 \\
\text { Aprendizagem docente } \\
\text { (segmento P-S) }\end{array}$ & $\begin{array}{c}2 \\
\text { Ensino } \\
(\text { segmento P-E) }\end{array}$ & $\begin{array}{c}3 \\
\text { Aprendizagem discente } \\
(\text { segmento E-S })\end{array}$ \\
\hline $\begin{array}{c}\text { A } \\
\text { Epistêmica } \\
\text { (conhecimento) }\end{array}$ & $\begin{array}{c}1 \mathrm{~A} \\
\text { Diz respeito às relações } \\
\text { epistêmicas que o professor } \\
\text { estabelece com sua própria } \\
\text { aprendizagem }\end{array}$ & $\begin{array}{c}\text { 2A } \\
\text { Diz respeito às relações } \\
\text { epistêmicas que o professor } \\
\text { estabelece com o ensino } \\
\text { que pratica }\end{array}$ & $\begin{array}{c}\text { 3A } \\
\text { Diz respeito às relações } \\
\text { epistêmicas que o professor } \\
\text { estabelece com a } \\
\text { aprendizagem dos } \\
\text { estudantes }\end{array}$ \\
\hline $\begin{array}{c}\text { B } \\
\text { Pessoal } \\
\text { (sentido) }\end{array}$ & $\begin{array}{c}1 \mathrm{~B} \\
\text { Diz respeito às relações } \\
\text { pessoais que o professor } \\
\text { estabelece com sua própria } \\
\text { aprendizagem }\end{array}$ & $\begin{array}{c}\text { 2B } \\
\text { Diz respeito às relações } \\
\text { pessoais que o professor } \\
\text { estabelece com o ensino } \\
\text { que pratica }\end{array}$ & $\begin{array}{c}\text { 3B } \\
\text { Diz respeito às relações } \\
\text { pessoais que o professor } \\
\text { estabelece com a } \\
\text { aprendizagem dos } \\
\text { estudantes }\end{array}$ \\
\hline $\begin{array}{c}\text { C } \\
\text { Social } \\
\text { (valor) }\end{array}$ & $\begin{array}{l}1 \mathrm{C} \\
\text { Diz respeito às relações } \\
\text { sociais que o professor } \\
\text { estabelece com sua própria } \\
\text { aprendizagem }\end{array}$ & $\begin{array}{c}2 \mathrm{C} \\
\text { Diz respeito às relações } \\
\text { sociais que o professor } \\
\text { estabelece com o ensino } \\
\text { que pratica }\end{array}$ & $\begin{array}{c}3 \mathrm{C} \\
\text { Diz respeito às relações } \\
\text { sociais que o professor } \\
\text { estabelece com a } \\
\text { aprendizagem dos } \\
\text { estudantes }\end{array}$ \\
\hline
\end{tabular}

Fonte: Arruda e Passos (2017, p.105)

Para elucidar um pouco mais a respeito do instrumento e das formas de utilizá-lo para analisar a ação do professor, trazemos na sequência uma explicação elaborada pelos próprios autores da Matriz do Professor.

A Matriz $\mathrm{M}(\mathrm{P})[\ldots]$ permite três tipos de leitura. Em uma leitura vertical ela mostra as percepções epistêmicas, pessoais e sociais do professor: sobre a aprendizagem docente (coluna 1); sobre o ensino que pratica (coluna 2); sobre a aprendizagem discente (coluna 3). Em uma leitura horizontal a Matriz $\mathrm{M}(\mathrm{P})$ apresenta as percepções do professor sobre a aprendizagem docente, sobre o ensino que pratica e sobre a aprendizagem discente do ponto de vista: epistêmico (linha A); pessoal (linha B); social (linha C). Essas duas leituras permitem uma visão geral das percepções e ações do professor sobre as relações com o saber escolar em sala de aula. Além disso, é possível, também, a realização da leitura célula a célula, que nos fornece uma visão mais detalhada das percepções do mesmo. As três leituras são complementares e, às vezes, utilizadas simultaneamente na análise dos dados (ARRUDA; PASSOS, 2017, p.104-105).

Além disso, é preciso esclarecer o que significam as linhas e colunas dessa matriz. As linhas se referem a três tipos de relações com o saber (ARRUDA; PASSOS, 2017, p.99): as relações epistêmicas com os saberes escolares, que estariam mais relacionados com os processos de

${ }^{8}$ Para mais detalhes a respeito do referencial teórico utilizado para a elaboração do instrumento referido, indicamos a leitura do artigo de Arruda, Lima e Passos (2011). 
compreensão dos conteúdos disciplinares; as relações pessoais, que teriam mais a ver com os sentimentos e a formação do sentido desses saberes para o professor; e as relações sociais, relacionadas com o fato de que o professor está imerso em uma comunidade de educadores (professores do ensino básico, professores universitários, pesquisadores, administradores etc.), em contato com seus valores e crenças, além dos pais e dos alunos.

Com relação às colunas, estas se referem ao modelo de sala de aula utilizado com frequência por vários educadores e que poderia ser denominado de triângulo didático-pedagógico, conforme a Figura 1 a seguir:

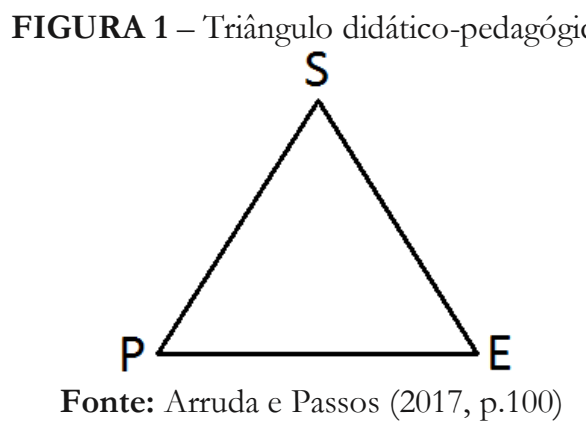

No qual P é o professor, E os alunos e S o saber a ser ensinado. Portanto, no Quadro 2 os segmentos se referem ao triângulo da Figura 1, que representa as relações com o saber em sala de aula de P e E.

A maneira com a qual utilizamos a $\mathrm{M}(\mathrm{P})$ foi diferente da forma com que esses autores de origem o fizeram, pois encontramos categorias que descreviam as ações docentes observadas nas aulas dos dois professores observados durante nossa coleta de dados e alocamos tais categorias de ação docente nos setores da $\mathrm{M}(\mathrm{P})$. Para a compreensão desses procedimentos trazemos diversos esclarecimentos na próxima seção, inclusive alguns detalhes a respeito do ambiente de coleta de dados, ou seja, da escola portuguesa investigada e dos sujeitos participantes.

\section{FUNDAMENTOS METODOLÓGICOS}

Com o intuito de fundamentar nossa metodologia de coleta e análise de dados, baseamo-nos em alguns procedimentos da Análise Textual Discursiva (ATD). Compreendemos que essa modalidade de análise textual possui características pertinentes às necessidades da nossa investigação, pois proporciona um processo auto-organizado que possibilita a superação de uma leitura convencional.

Esta modalidade também possui a pretensão de elaborar "compreensões sociais e culturais relativas ao fenômeno que investiga [trazendo consigo um sentido] radicalmente hermenêutico" (MORAES; GALIAZZI, 2011, p.147).

A ATD possui quatro etapas que constituem os procedimentos por ela requisitados:

Etapa 1 - A desmontagem dos textos é "o primeiro elemento do ciclo de análise" (MORAES; GALIAZZI, 2011, p.13) que constitui a ATD. Para alcançar diferentes interpretações a partir da leitura de um texto é preciso, em primeiro lugar, constituir "um conjunto adequado de documentos a serem analisados" (MORAES; GALIAZZI, 2011, p.17) e, depois, iniciar a desmontagem desses textos.

Etapa 2 - A desconstrução e a unitarização são o segundo elemento do ciclo da ATD com o objetivo de explorar interpretações novas em um texto. Sendo assim, é possível averiguar, nos detalhes das transcrições realizadas, sentidos que uma simples leitura seria incapaz de obter. Posteriormente à desconstrução textual, o próximo passo é o movimento no sentido inverso, buscando a convergência dos elementos desconstruídos (movimento denominado de unitarização). Complementam os autores que "a unitarização é parte do esforço de construir significados a partir de um conjunto de textos, entendendo que sempre há mais sentidos do que uma leitura possibilita elaborar" (MORAES; GALIAZZI, 2011, p.49). 
Etapa 3 - Após a desconstrução do texto, estabelece-se a terceira etapa do ciclo da ATD, que diz respeito à categorização. Trata-se de "um processo de comparação constante entre as unidades definidas no momento inicial da análise, levando a agrupamentos de elementos semelhantes" (MORAES; GALIAZZI, 2011, p.23).

Etapa 4 - O último dos elementos constituintes do ciclo de procedimentos da ATD é a construção do metatexto, no qual são expressos "os sentidos lidos em um conjunto de textos constituídos de descrição e interpretação, representando o conjunto, um modo de teorização sobre os fenômenos estudados" (MORAES; GALIAZZI, 2011, p.32).

Essas quatro etapas formam um ciclo de procedimentos que permitem novas interpretações acerca dos dados constituídos, e que nortearam a coleta e análise dos dados referentes a esta pesquisa.

Para a seleção do ambiente de coleta de dados e dos sujeitos de pesquisa, foram estabelecidos critérios a partir das indicações de pesquisadores da Universidade Portuguesa ${ }^{9}$. Estes pesquisadores possuíam acesso à escola e contato com os professores. Escolhemos, portanto, dois professores dentre suas indicações após conversas, entrevistas iniciais e permissão para a filmagem das aulas.

Sendo assim, durante um período de aproximadamente três meses, entre o início de janeiro e o início de março de 2016, iniciamos a tomada de dados na referida escola de Portugal. Ao todo, foram mais de 50 horas de observação de aulas gravadas em áudio e vídeo; para este artigo selecionamos 3 aulas do professor codificado como P1 e 2 aulas do professor P2, respectivamente, uma hora e meia e uma hora e quinze minutos, aproximadamente. Selecionamos somente essas aulas, das tantas que possuímos, pois elas são representativas das atuações desses professores em sala de aula, justificando que a apresentação de uma quantidade excessiva de aulas não se adequaria a um artigo pela quantidade de informação que possuem.

A escola em questão faz parte de um agrupamento de escolas, que se distribuem por certa região de Portugal, possuindo naquela ocasião: cinco Jardins de Infância; duas escolas de primeiro ciclo; uma escola do segundo e terceiro ciclos ${ }^{10}$ e do Ensino Secundário. Nós pesquisamos uma escola que atendia alunos pertencentes ao primeiro ciclo, com faixa etária aproximada entre 7 e 10 anos. Foi nela que coletamos as aulas analisadas e aqui apresentadas. Todo o processo de coleta foi realizado por meio de videogravação de suas atuações, que, posteriormente, tiveram a transcrição de suas falas, a descrição das ações não verbais e transcrição das falas de seus alunos.

Quanto aos professores estudados, inserimos no Quadro 3 algumas informações sobre eles.

QUADRO 3 - Informações sobre os professores pesquisados

\begin{tabular}{|l|l|}
\hline Professor 1 (P1) & $\begin{array}{l}\text { Professor do } 4^{\circ} \text { ano do Primeiro Ciclo (equivalente ao } 4^{\circ} \text { ano do Ensino Fundamental I } \\
\text { brasileiro). }\end{array}$ \\
\hline Idade & 48 anos (em janeiro de 2016). \\
\hline Classe & 26 alunos (4 sem autorização) ${ }^{11}$. \\
\hline Formação & $\begin{array}{l}\text { Magistério Primário; } \\
\text { Licenciatura em Letras; } \\
\text { Complemento em formação para professores do Primeiro Ciclo; } \\
\text { Cursos de formação em "Educação Formal e Não Formal em Ciências: Abordagens Didáticas } \\
\text { Integradas para os Primeiros Anos de Escolaridade" e "Práticas Integradas de Educação Formal e } \\
\text { Não Formal em Ciências", realizados durante a atuação profissional na escola em questão. }\end{array}$ \\
\hline $\begin{array}{l}\text { Experiência na } \\
\text { docência }\end{array}$ & $\begin{array}{l}27 \text { anos; } \\
10 \text { anos na escola investigada, ou seja, desde sua inauguração. }\end{array}$ \\
\hline Professor 2 (P2) & Professor do 2 $2^{\circ}$ ano do Primeiro Ciclo (equivalente ao 20 ano do Ensino Fundamental I \\
\hline
\end{tabular}

\footnotetext{
${ }^{9}$ Os pesquisadores portugueses a que nos referimos foram nossos orientadores durante o período de doutorado sanduíche no exterior.

${ }^{10} 1^{\circ}$ ciclo equivale aos $1^{\circ}, 2^{\circ}, 3^{\circ}$ e $4^{\circ}$ anos. $2^{\circ}$ ciclo equivale aos $5^{\circ}$ e $6^{\circ}$ anos. $3^{\circ}$ ciclo equivale aos $7^{\circ}, 8^{\circ}$ e $9^{\circ}$ anos do Ensino Fundamental do Brasil. O ensino secundário é equivalente ao nosso Ensino Médio.

${ }^{11}$ Alguns pais de alunos não autorizaram que seus filhos fossem filmados e que suas falas fossem utilizadas na pesquisa. 


\begin{tabular}{|l|l|}
\hline & brasileiro). \\
\hline Idade & 40 anos (em janeiro de 2016). \\
\hline Classe & 26 alunos (7 sem autorização). \\
\hline Formação & $\begin{array}{l}\text { Formação para professores do } 2^{\circ} \text { Ciclo do Ensino Básico com variante em Educação visual e } \\
\text { Tecnológica com equivalência para o } 1^{\circ} \text { Ciclo. }\end{array}$ \\
\hline $\begin{array}{l}\text { Experiência na } \\
\text { docência }\end{array}$ & $\begin{array}{l}15 \text { anos; } \\
1^{\circ} \text { ano na escola investigada. }\end{array}$ \\
\hline
\end{tabular}

Fonte: os autores

Ao ser contatado, P1 demonstrou muita solicitude para participar da pesquisa, mostrou-se uma pessoa confiável, com amplo conhecimento acerca de diversas áreas. Ministrou suas aulas com segurança e firmeza, gerenciando a sua classe de 26 alunos. Seus alunos foram classificados com uma codificação entre E1 e E22, pois quatro deles não trouxeram a autorização, assinada por seus responsáveis, para serem videogravados.

P2 atuava como professor substituto naquela escola, era seu primeiro ano por lá; contudo, possuía grande experiência na docência. Ele também se mostrou disponível em participar da pesquisa, todavia modificou sua maneira de ensinar a partir da leitura das expressões faciais de seus alunos para atender ao que chamou de necessidades de aprendizagem dos estudantes, estando sempre atento ao que ocorria na sala de aula, tecendo elogios aos alunos e repreendendo-os com frequência diante das situações ocorridas. Seus alunos foram classificados com uma codificação de E1 até E18, sendo que sete foram os alunos não autorizados pelos pais.

Trazemos agora a descrição dos procedimentos realizados para a constituição e organização dos dados recolhidos.

\section{Constituição e organização dos dados}

Para que pudéssemos ser capazes de analisar os dados constituídos foi necessário utilizar os dois instrumentos simultaneamente. A solução então foi integrar os dois instrumentos, ou seja, integrar o Quadro dos objetivos e motivos da ação de Tardif e Lessard (2008) com a Matriz do Professor de Arruda e Passos (2017). Desse processo chegamos a uma maneira inédita de organizar os dados e que pode ser consultada no Quadro 4, com exemplo de um trecho da aula de P1, em que o professor interage com um dos alunos.

QUADRO 4 - Forma de organização dos dados: fragmento da aula de P1

\begin{tabular}{|l|c|c|}
\hline $\begin{array}{c}\text { Numeração } \\
\text { da ação }\end{array}$ & Categoria de ação docente: Setor da Matriz & $\begin{array}{c}\text { Transcrição das falas/descrição das ações docentes } \\
\text { não verbais }\end{array}$ \\
\hline 48. & $\begin{array}{c}\text { Pergunta que conduz ao raciocínio para um } \\
\text { aluno: 3A }\end{array}$ & O que é um produto, E21? \\
\hline 49. & \multicolumn{2}{|c|}{ E21: É uma multiplicação. } \\
\hline 50. & Correção: 2A & É o resultado de uma multiplicação. \\
\hline 51. & Elogio: 3B & Muito bem! \\
\hline
\end{tabular}

Fonte: os autores

Para cada uma das colunas do Quadro anterior elaboramos uma explicação a fim de facilitar a compreensão da forma como procedemos para organizar os dados:

1. Numeração da ação: refere-se à sequência das ações que foram desenvolvidas na aula em questão. Para o trecho citado anteriormente, temos da $48^{\mathrm{a}}$ até a $51^{\mathrm{a}}$ ação que foi realizada na aula de P1. Após realizada a elaboração das categorias de ação, realizamos a contagem da frequência em que elas foram observadas em cada aula, e isso nos levou a extrair as porcentagens das categorias de ação docente realizadas pelos professores $[\ldots]$ nas aulas que ministraram;

\footnotetext{
${ }^{12}$ Foram enumeradas ações dos professores e monitores e também dos alunos. No entanto, analisamos somente as ações docentes para apresentar neste artigo. 
2. Categoria de ação docente/Setor da Matriz: diz respeito à categoria da ação que o professor [...] desenvolveu e também ao setor da Matriz correspondente a essa ação;

3. Transcrição das falas/descrição das ações docentes não verbais: refere-se à transcrição das falas e à descrição de algumas ações não verbais (ações em que o professor [...] escreve ou aponta para o quadro, realiza gestos de aprovação ou carinho, sorri etc.) do professor durante a sua atuação em sala de aula coletadas por meio de videogravação. Diz respeito ao que, de fato, o professor disse ou fez (PIRATELO, 2018).

Em síntese, para compor a análise dos dados, a partir dos procedimentos da ATD, realizamos os seguintes passos: 1 - Transcrição e leitura dos dados provenientes das gravações em áudio e vídeo de uma hora e meia e uma hora e quinze minutos das aulas de P1 e P2, respectivamente; 2 - Fragmentação e desconstrução das transcrições das aulas; 3 - Unitarização dos dados que nos proporcionaram um conjunto de categorias de ações docentes; 4 - Alocação desse conjunto de categorias de ação docente nos setores da $\mathrm{M}(\mathrm{P})$.

Sempre considerando que nosso objetivo, ao compor a análise dos dados, era o de elaborar categorias de ação que emergissem da observação das aulas dos dois professores, descrevendo tais categorias e produzindo um texto interpretativo sobre elas. Estas categorias de ação docente encontradas estão no apêndice no final deste artigo ${ }^{13}$.

$\mathrm{Na}$ continuidade, elaboramos uma seção em que são apresentados os dados interpretados e que sustentaram as considerações conclusivas a que chegamos.

No sentido de garantir a alocação mais coerente das ações docentes, recorremos a uma descrição de cada uma das células da Matriz do Professor, encontradas em Arruda, Lima e Passos (2011, p.147-148) e reproduzidas no Anexo.

\section{APRESENTAÇÃO E ANÁLISE DOS DADOS}

Esta seção foi estruturada da seguinte forma: inicialmente, apresentamos algumas informações a respeito da aula do professor em questão e descrevemos brevemente como ocorreu a aula observada; em seguida trazemos um Quadro em que utilizamos nossa forma de organizar os dados para mostrar um trecho da aula, com a categorização das ações docentes observadas e sua classificação nos setores da $\mathrm{M}(\mathrm{P})$; logo após, inserimos uma versão da $\mathrm{M}(\mathrm{P})$ com os setores preenchidos com as porcentagens das frequências de categorias de ação docente encontradas nas aulas dos professores, segundo nossa interpretação.

Iniciamos, portanto, com a apresentação dos dados referente à aula de P1 e em seguida discorreremos sobre a aula de P2.

\section{A Aula de P1}

No Quadro 5 temos algumas informações relativas à aula de P1 analisada.

QUADRO 5 - Informações a respeito da aula de P1

\begin{tabular}{|l|c|}
\hline Data & $27 / 01 / 2016$ \\
\hline Duração & $1 \mathrm{~h} \mathrm{32}$ min (3 aulas) \\
\hline Aula de Matemática & Multiplicação por 10, por 100, por 1000, por 0,1, por 0,01 e por \\
& 0,001 \\
\hline Número total de ações & 928 \\
\hline Número de ações docentes & 658 \\
\hline Número de ações dos alunos ${ }^{14}$ & 270 \\
\hline
\end{tabular}

Fonte: os autores

\footnotetext{
13 Nesse apêndice descrevemos tais categorias, justificamos sua alocação no devido setor da Matriz do Professor e apresentamos algumas ações desenvolvidas pelos professores em sala de aula, para exemplificar a categoria escolhida por nós.

${ }^{14}$ As ações dos alunos não foram categorizadas, portanto, preferimos nomear como ações dos alunos e não como categorias de ação discente.
} 
A aula de P1 de Matemática teve a duração aproximada de 1 hora e meia. Ao iniciar sua aula, o professor propôs aos alunos, por meio do quadro interativo ${ }^{15}$, um problema matemático apresentado na forma de um diálogo entre dois alunos - Quando obtemos um produto maior, quando multiplicamos um número por dez ou por uma décima?

A partir dessa situação-problema, o objetivo de P1 foi de que os alunos aprendessem as regras de multiplicação e divisão por dez, cem, mil, uma décima, uma centésima e uma milésima, e que seus alunos realizassem os cálculos, sem o uso de lápis, caneta, papel ou calculadora, ou seja, a partir do que chamou de "cálculo mental". P1 intencionava mostrar o que ocorria nas operações com as casas decimais dos números, e incentivá-los a chegarem à resposta do problema proposto no início da aula.

$\mathrm{Na}$ sequência, apresentamos no Quadro 6 um dos trechos iniciais da aula (ações de 13 a 19 que ocorreram na aula de P1) com as categorias de ação docente encontradas, além da transcrição de parte da aula, com nossa nova maneira de organizar os dados. Neste Quadro, também podemos perceber o quanto P1 fez uso de perguntas para conduzir sua aula.

QUADRO 6 - Trecho 1 da aula de P1

\begin{tabular}{|c|c|c|}
\hline $\begin{array}{c}\text { Numeração } \\
\text { da ação }\end{array}$ & $\begin{array}{c}\text { Categoria de ação } \\
\text { docente: Setor da } \\
\text { Matriz }\end{array}$ & Transcrição das falas/descrição das ações docentes não verbais \\
\hline 13. & $\begin{array}{l}\text { Introdução de um } \\
\text { problema: } 2 \mathrm{~A}\end{array}$ & $\begin{array}{l}\text { Eu tenho ali dois meninos a conversar e vamos ver o que eles estão a } \\
\text { conversar. Os dois estão de mochila às costas, provavelmente ou irão à escola } \\
\text { ou estão indo para a escola. E a conversa que eles têm também é sobre } \\
\text { assuntos da escola. Este menino do chapéu vermelho diz assim: Quando é } \\
\text { que obtemos um produto maior, multiplicando um número por dez ou por } \\
\text { uma décima? Esta é a pergunta que este menino da camisola amarela faz. }\end{array}$ \\
\hline 14. & Pergunta retórica: $2 \mathrm{~A}$ & Sabem o que é um produto? \\
\hline 15. & $\begin{array}{c}\text { Pergunta que conduz } \\
\text { ao raciocínio para a } \\
\text { classe: } 3 \mathrm{~A}\end{array}$ & Quando nós queremos um produto, que operação fazemos? \\
\hline 16. & & E6: Fazemos uma multiplicação. \\
\hline 17. & Parecer/retorno: $2 \mathrm{~A}$ & $\begin{array}{l}\text { Exatamente! E então ele pergunta se nós obtemos um número maior se } \\
\text { multiplicarmos por dez ou se multiplicarmos por uma décima. }\end{array}$ \\
\hline 18. & $\begin{array}{c}\text { Pergunta que conduz } \\
\text { ao raciocínio para a } \\
\text { classe: } 3 \mathrm{~A}\end{array}$ & E o que é que o amigo responde? \\
\hline 19. & \multicolumn{2}{|c|}{ E11: Não sei, é melhor verificarmos para chegarmos a uma conclusão. } \\
\hline
\end{tabular}

Fonte: os autores

Apresentamos agora, no Quadro 7, uma versão da $\mathrm{M}(\mathrm{P})$ em que as categorias de ação docente encontradas na aula analisada foram alocadas nos setores do instrumento, ou seja, as 658 ações docentes, protagonizadas por $\mathrm{P} 1$, mapeando a $\mathrm{M}(\mathrm{P})$ em 4 dos 9 setores da Matriz (destacados em cinza) perfazendo os 100\% de suas atuações.

QUADRO 7 - Porcentagens das frequências de categorias de ação docente de P1 em M(P)

\begin{tabular}{|c|c|c|c|c|}
\hline Relações do professor & $\begin{array}{c}1 \\
\text { com o conteúdo } \\
\text { (Segmento P-S) }\end{array}$ & $\begin{array}{c}2 \\
\text { com o ensino } \\
\text { (Segmento P-E) }\end{array}$ & $\begin{array}{c}3 \\
\text { com a aprendizagem } \\
\text { (Segmento E-S) }\end{array}$ \\
\hline $\begin{array}{c}\text { Relações } \\
\text { com o saber }\end{array}$ & $\begin{array}{c}\text { Setor 1A } \\
\text { E }\end{array}$ & $\begin{array}{c}\text { Setor } 2 \mathrm{~A} \\
51 \%\end{array}$ & $\begin{array}{c}\text { Setor } 3 \mathrm{~A} \\
33 \%\end{array}$ & $84 \%$ \\
\hline
\end{tabular}

15 O quadro interativo é uma superfície que pode reconhecer a escrita eletronicamente. Era uma ferramenta muito utilizada pelos professores da escola. 


\begin{tabular}{|c|c|c|c|c|}
\hline B & Setor 1B & Setor 2B & Setor 3B & $4 \%$ \\
Pessoal & $0 \%$ & $0 \%$ & $4 \%$ & $12 \%$ \\
\hline C & Setor 1C & Setor 2C & Setor 3C & $0 \%$ \\
\hline Social & $0 \%$ & $12 \%$ & $37 \%$ & $100 \%$ \\
\hline Totais & $0 \%$ & $63 \%$ & $\%$ & 0 \\
\hline
\end{tabular}

Fonte: os autores

Ao observarmos o Quadro 7, considerando as informações que alocamos nas colunas (Relações do professor: 1 - com o conteúdo; 2 - com o ensino; e, 3 - com a aprendizagem), vemos que as categorias de ação se manifestaram principalmente na relação com o ensino. Quando consideramos a disposição nas linhas (A - Epistêmica; B - Pessoal; e, C - Social) vemos que suas ações foram predominantemente situadas nos aspectos epistêmicos. Os dois principais setores em que as categorias de ação foram alocadas dizem respeito aos setores $2 \mathrm{~A}$ e $3 \mathrm{~A}$, ou seja, ações protagonizadas pelo professor no intuito de promover o ensino e ações em que ele almejou que os protagonistas fossem os alunos para promover a aprendizagem, respectivamente.

$\mathrm{O}$ fato de não haver categorias alocadas nos setores relativos à coluna 1 , correspondente à relação do professor com o conteúdo, é devido à interpretação que nós pesquisadores, e que o grupo de pesquisa ao qual pertencemos, atribuímos à análise dos dados na Matriz desde que ela foi elaborada em 2011. Embora o professor tenha abordado o conteúdo, e que este tenha sido o assunto sobre o qual toda a aula foi desenvolvida, nossa interpretação é a de que as categorias de ação poderiam ser alocadas na coluna 1, quando o professor lê, cita ou escreve (na íntegra) um conteúdo disponibilizado em um material previamente elaborado, podendo este estar disponível em livros, na internet etc. Pode-se incluir também nesta coluna 1 as manifestações de sentimentos ou valores com relação ao conteúdo abordado, ou seja, quando o professor comenta gostar ou não da matéria que ensina ou quando manifesta que a considera importante ou não durante sua aula.

As categorias de ações em que os professores buscaram fazer uso de diferentes maneiras para ensinar o conteúdo, encontram-se alocadas nos setores referentes à coluna 2, correspondente à relação do professor com o ensino. Por este motivo, podemos ver que os setores referentes à coluna 1 obtiveram uma porcentagem nula de categorias de ações alocadas, e os setores relativos à coluna 2 obtiveram uma porcentagem relevante nas análises dos dados.

\section{A Aula de P2}

Assim como apresentamos e analisamos a atuação do P1, passamos agora à descrição e análise do que realizou P2 em sua aula, trazendo de antemão informações sobre o professor (Quadro 8); em seguida, trechos da aula para exemplificação (Quadro 9) e da alocação de todas as acomodações (em percentagens) do que ocorreu na Matriz (Quadro 10).

QUADRO 8 - Informações a respeito da aula de P2

\begin{tabular}{|c|c|}
\hline Data & $02 / 02 / 2016$ \\
\hline Duração & $1 \mathrm{~h} 14$ min (2 aulas) \\
\hline Aula de Matemática e Estudo do Meio & Os estados do tempo \\
\hline Número total de ações & 466 \\
\hline Número de ações docentes categorizadas de P2 & 367 \\
\hline Número de ações dos alunos & 99 \\
\hline
\end{tabular}

Esta aula videogravada teve início como uma continuação da aula de Matemática do horário anterior e, na sequência, foi uma aula de Estudo do Meio, conforme agenda de horário da turma. O tema da aula foi sobre os estados do tempo do mês de janeiro de 2016, onde um aluno apresentou anotações diárias do clima desse mês e P2 trabalhou conceitos relativos à contagem e frequência dos dias de sol, de chuva etc.

P2 utilizou-se de diversas estratégias pedagógicas para atingir os objetivos que propôs à aula, e as modificou sempre que julgou necessário, pois em suas palavras a intenção era "atingir mais 
alunos". Sendo assim, esse professor explicou verbalmente o conteúdo, dirigiu diversas perguntas aos alunos, supervisionou frequentemente nas carteiras as atividades que propôs e elogiou seus alunos sempre que concluía que haviam realizado o que pediu.

A seguir, apresentamos um trecho da aula de P2 no Quadro 9. Neste Quadro, podemos perceber que P2 se utiliza da lousa para a resolução de exercícios, elogia um aluno que resolveu corretamente o exercício e volta a supervisionar o restante dos alunos para conferir se realizaram a atividade.

QUADRO 9 - Trecho 2 da aula de P2

\begin{tabular}{|c|c|c|}
\hline $\begin{array}{l}\text { Numeração da } \\
\text { ação }\end{array}$ & Categoria de ação docente: Setor da Matriz & $\begin{array}{c}\text { Transcrição das falas/descrição das ações docentes não } \\
\text { verbais }\end{array}$ \\
\hline 15. & Escrita no quadro: $2 \mathrm{~A}$ & $\begin{array}{c}\text { P2 escreve no quadro: } \\
383-141= \\
\end{array}$ \\
\hline 16. & Pergunta sem sentido: $3 \mathrm{~A}$ & E12, o que está a fazer? \\
\hline 17. & Escrita no quadro: $2 \mathrm{~A}$ & P2 escreve no quadro: $313+106$ \\
\hline 18. & $\begin{array}{l}\text { Chamada de atenção relacionada ao } \\
\text { conteúdo: } 2 \mathrm{~A}\end{array}$ & Vá lá! Quem já acabou vai fazendo a continha. \\
\hline 19. & Incentivo à resposta de um aluno: $3 \mathrm{~A}$ & Diz (aluno sem autorização) \\
\hline 20. & \multicolumn{2}{|c|}{ Fala de aluno sem autorização } \\
\hline 21. & Elogio: 3B & Boa, muito bem! Linda menina! \\
\hline 22. & Escrita no quadro: $2 \mathrm{~A}$ & $\begin{array}{l}\text { P2 escreve a resposta no quadro: } \\
242 \\
\end{array}$ \\
\hline 23. & Supervisão/correção dos exercícios: $2 \mathrm{~A}$ & P2 caminha pela sala e se posiciona no centro. \\
\hline
\end{tabular}

Fonte: os autores

Da mesma forma como procedemos em relação aos dados apresentados sobre a aula de P1, fizemos com P2. Sendo assim, distribuímos as categorias de ação docente que emergiram da aula de P2 na Matriz do Professor no Quadro 10 a seguir, realizamos a contagem da frequência em que foram executadas e calculamos a porcentagem dessas ações em relação ao total de 367 ações desempenhadas por este professor, destacando em cinza os setores em que foi possível alocar ao menos uma categoria de ação ou objetivo e motivo da ação docente, mesmo que não houvesse porcentagem relevante.

QUADRO 10 - Porcentagens das frequências de categorias de ação docente de P2 em M(P)

\begin{tabular}{|c|c|c|c|c|}
\hline $\begin{array}{r}\begin{array}{r}\text { Relações do } \\
\text { professor }\end{array} \\
\text { Relações } \\
\text { com o saber }\end{array}$ & $\begin{array}{c}1 \\
\text { com o conteúdo } \\
\text { (Segmento P-S) }\end{array}$ & $\begin{array}{c}2 \\
\text { com o ensino } \\
(\text { Segmento P-E) }\end{array}$ & $\begin{array}{c}3 \\
\text { com a aprendizagem } \\
\text { (Segmento E-S) }\end{array}$ & Totais \\
\hline $\begin{array}{c}\text { A } \\
\text { Epistêmica }\end{array}$ & $\begin{array}{c}\text { Setor } 1 \mathrm{~A} \\
0 \%\end{array}$ & $\begin{array}{c}\text { Setor } 2 \mathrm{~A} \\
70 \%\end{array}$ & $\begin{array}{c}\text { Setor } 3 \mathrm{~A} \\
18 \%\end{array}$ & $88 \%$ \\
\hline $\begin{array}{c}\text { B } \\
\text { Pessoal }\end{array}$ & $\begin{array}{c}\text { Setor } 1 \mathrm{~B} \\
0 \%\end{array}$ & $\begin{array}{c}\text { Setor } 2 \mathrm{~B} \\
0 \%\end{array}$ & $\begin{array}{c}\text { Setor } 3 \mathrm{~B} \\
3 \%\end{array}$ & $3 \%$ \\
\hline $\begin{array}{c}\text { C } \\
\text { Social }\end{array}$ & $\begin{array}{c}\text { Setor } 1 \mathrm{C} \\
0 \%\end{array}$ & $\begin{array}{c}\text { Setor } 2 \mathrm{C} \\
9 \%\end{array}$ & $\begin{array}{c}\text { Setor } 3 \mathrm{C} \\
0 \%\end{array}$ & $9 \%$ \\
\hline Totais & $0 \%$ & $79 \%$ & $21 \%$ & $100 \%$ \\
\hline
\end{tabular}

Fonte: os autores

As categorias de ações encontradas na aula de P2 foram alocadas em seis dos nove setores destacados em cinza na $\mathrm{M}(\mathrm{P})$. Em dois deles, a frequência foi muito pequena e, em comparação ao total de 367 ações, representaram menos de 1\%. Sendo assim, os setores com porcentagem relevante acerca das categorias de ação docente foram os mesmos de P1, todavia as semelhanças com a aula deste outro professor também se manifestam por meio dos descritivos numéricos. A coluna com a 
maior incidência de categorias de ação docente também foi a coluna 2, referente ao ensino e, a linha com maior porcentagem de categorias de ação foi a linha $\mathrm{A}$, da relação epistêmica com o saber. $\mathrm{O}$ setor com maior porcentagem foi o $2 \mathrm{~A}$, e o segundo com maior porcentagem foi o $3 \mathrm{~A}$, assim como foi com P1.

Para facilitar essa comparação, que em momento algum teve a pretensão de ser avaliativa, com caráter de julgamento a respeito das melhores práticas a serem realizadas em sala de aula, inserimos os dados obtidos nos Quadros 7 e 10 em um único gráfico, o Gráfico 1 a seguir.

GRÁFICO 1 - Representação das porcentagens alocadas nas M(P) de P1 e P2

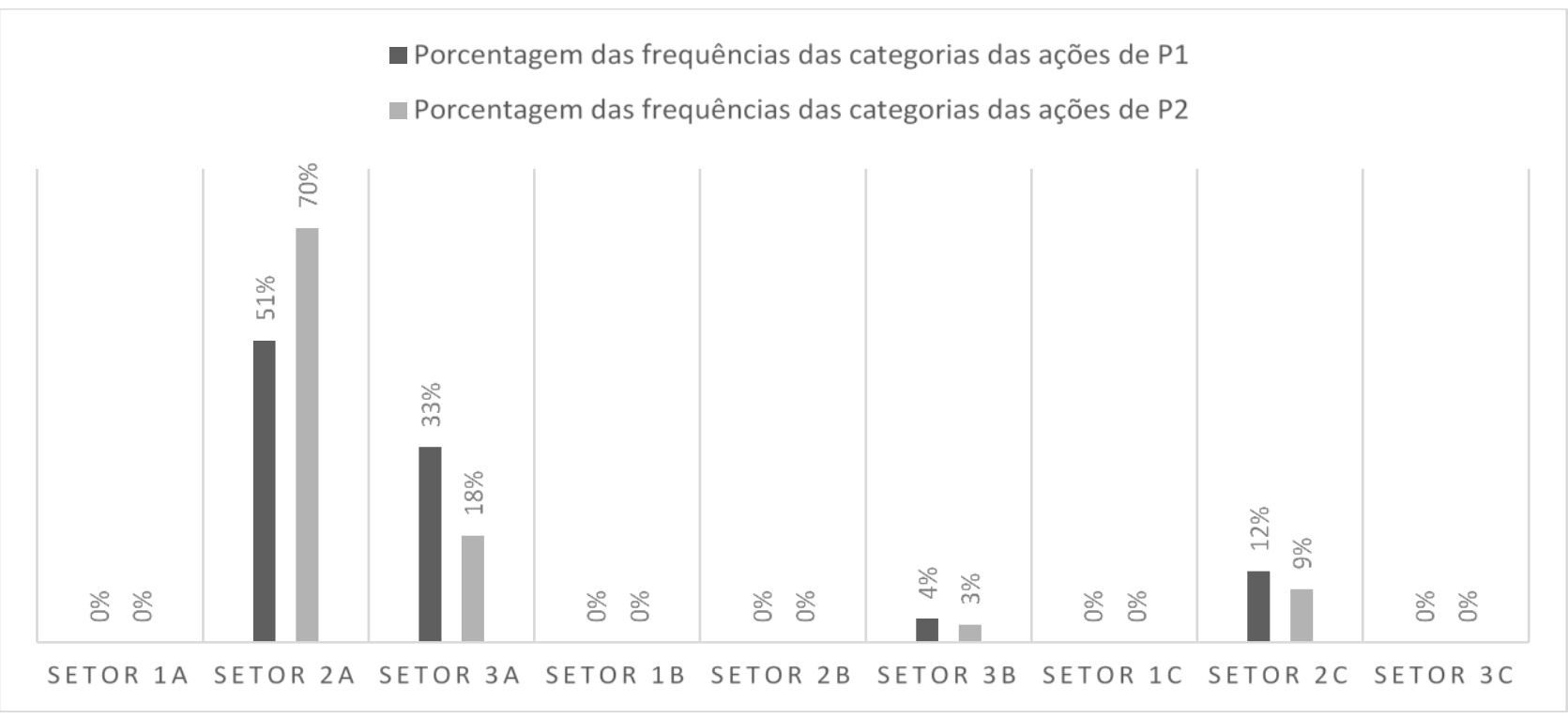

Fonte: os autores

Esse gráfico nos permitiu realizar algumas interpretações. Os setores com relevância, no que diz respeito à porcentagem da frequência das categorias de ação docente na aula de P1 e P2, foram os mesmos. Além disso, existem alguns setores de maior incidência do que outros e, para os dois professores, esses setores também foram os mesmos. Isso nos levou a inferir que o ambiente de sala de aula pode ser um fator que corrobora com as ações desenvolvidas pelo professor ${ }^{16}$. A principal diferença encontra-se na porcentagem referente a cada setor, e esse fato pode estar relacionado ao estilo de aula de cada docente.

\section{CONSIDERAÇÕES FINAIS}

Iniciamos este artigo buscando descrever e analisar as categorias de ação docente de dois professores de uma escola portuguesa, fundamentando-nos, para isso, no Quadro de motivos e objetivos da ação de Tardif e Lessard (2008) e na Matriz do Professor de Arruda e Passos (2017). Os procedimentos metodológicos pautaram-se naquilo que a Análise Textual Discursiva defende e que nos proporcionou elaborar uma nova maneira de organizar os dados, que foi capaz de atender às necessidades investigativas relativas a este estudo identificando:

- As categorias de ação docente realizadas pelos professores. Por meio da análise da gravação das aulas desses dois professores foi possível caracterizar 47 categorias de ação docente distintas.

${ }^{16}$ Diversos detalhes e inúmeras informações sobre essa pesquisa podem ser consultados em Piratelo (2018). 
- A porcentagem da frequência das categorias de ação docente observadas. Diante da contagem da frequência das categorias de ações e de cálculos de percentagens referentes a cada uma dessas categorias, pudemos ilustrar um perfil de ação docente relativo a cada aula observada ${ }^{17}$.

As categorias de ação docente que emergiram dos dados encontram-se dispostas no apêndice no final do artigo, no qual descrevemos e apresentamos as justificativas para as classificações nos setores da Matriz do Professor a elas atribuídas. A título de exemplo, trazemos aqui parte do apêndice na forma de um quadro. Nele, descrevemos a codificação da ação docente em que atribuímos os números de 1 a 47 para cada categoria de ação encontrada (no Quadro 11 a seguir, trazemos apenas 3); a nomenclatura atribuída à categoria da ação e o setor da Matriz do Professor em que foi alocada; a descrição dessa categoria; a justificativa da alocação dessa categoria de ação no referido setor e um exemplo de ação efetuada por um dos professores analisados durante sua atuação.

QUADRO 11 - Descrição de três categorias e justificação para alocação nos setores da M(P)

\begin{tabular}{|c|c|c|c|c|}
\hline $\begin{array}{l}\text { Codificação } \\
\text { da ação } \\
\text { docente }\end{array}$ & $\begin{array}{l}\text { Categoria de } \\
\text { ação docente/ } \\
\text { Setor da Matriz }\end{array}$ & $\begin{array}{l}\text { Descrição da categoria de } \\
\text { ação docente }\end{array}$ & $\begin{array}{c}\text { Justificativa para alocação nos } \\
\text { setores da Matriz }\end{array}$ & $\begin{array}{l}\text { Exemplos de ações } \\
\text { docentes } \\
\text { observadas em sala } \\
\text { de aula }\end{array}$ \\
\hline 1. & $\begin{array}{l}\text { Atribuição de } \\
\text { atividades para } \\
\text { a aula: } 3 \mathrm{~A}\end{array}$ & $\begin{array}{l}\text { O professor atribui tarefas } \\
\text { a serem realizadas no } \\
\text { ambiente de sala de aula. }\end{array}$ & $\begin{array}{l}\text { 3A - Esta ação docente possui } \\
\text { relação com a tentativa do professor } \\
\text { de fazer com que seus alunos } \\
\text { compreendam, por meio de } \\
\text { exercícios, o conteúdo abordado. }\end{array}$ & $\begin{array}{l}\text { P2: P2 distribui as } \\
\text { fichas à classe. }\end{array}$ \\
\hline 2. & $\begin{array}{l}\text { Atribuição de } \\
\text { atividades para } \\
\text { casa: 3A }\end{array}$ & $\begin{array}{l}\text { O professor atribui tarefas } \\
\text { para que os alunos } \\
\text { cumpram em casa e } \\
\text { entreguem ao professor } \\
\text { em uma aula posterior. }\end{array}$ & $\begin{array}{l}\text { 3A - Tal ação docente diz respeito à } \\
\text { tentativa do professor de fazer com } \\
\text { que seus alunos compreendam, por } \\
\text { meio de exercícios a serem realizados } \\
\text { em casa, o conteúdo abordado. }\end{array}$ & $\begin{array}{l}\text { P1: Olha, hoje o } \\
\text { trabalho de casa é } \\
\text { estudar. Ah, pois é. }\end{array}$ \\
\hline 3. & $\begin{array}{l}\text { Atribuição de } \\
\text { funções para } \\
\text { alguns alunos: } \\
\text { 2C }\end{array}$ & $\begin{array}{c}\text { O professor distribui } \\
\text { funções aos alunos para a } \\
\text { organização do ambiente } \\
\text { de sala de aula. }\end{array}$ & $\begin{array}{l}\text { 2C - Esta ação docente relaciona-se } \\
\text { às negociações de valores do } \\
\text { professor com seus alunos para o } \\
\text { andamento da aula. }\end{array}$ & $\begin{array}{l}\text { P2: E3, retire as } \\
\text { fichas, faz um } \\
\text { favor. }\end{array}$ \\
\hline
\end{tabular}

\section{Fonte: os autores}

Como resultado das análises por meio da forma organizacional dos dados e da contagem das categorias de ação, averiguamos que nas duas aulas observadas, as categorias de ação encontradas recaíram sobre os mesmos setores da $\mathrm{M}(\mathrm{P})$ e na mesma ordem de importância (em primeiro lugar o setor $2 \mathrm{~A}$, na sequência $3 \mathrm{~A}$, depois $2 \mathrm{C}$ e por último $3 \mathrm{~B}$ ). Isso nos chamou a atenção para o fato de o ambiente de sala de aula ter a possibilidade de direcionar o tipo de ação a ser executada pelo professor. Além disso, verificamos que as percentagens das categorias de ação docente variaram, o que nos levou a interpretar que cada professor tem suas características pedagógicas e que isso também pode influenciar nas escolhas das ações e na frequência a serem desempenhadas durante a aula.

Também percebemos, durante a observação de várias aulas desses professores, alguns fatores que podem ser responsáveis pela diferenciação das práticas entre eles, como a frequência, a intensidade e a qualidade das ações docentes. A frequência, porque pode refletir o perfil docente e as principais preocupações do professor durante sua aula; a intensidade, por enfatizar a importância que o professor confere a determinada ação (por exemplo: a intensidade de uma punição ou chamada de atenção); e, a qualidade, por expressar a reflexão docente acerca de um determinado tema (exemplo: a qualidade da pergunta feita em sala que conduz o aluno ao raciocínio).

Em síntese, neste estudo priorizamos uma visão descritiva e analítica do que de fato ocorreu em sala de aula. A partir dessa perspectiva, também foi possível atribuir um viés interpretativo

\footnotetext{
${ }^{17}$ Reforçamos que o perfil encontrado a partir da análise por meio da Matriz do Professor diz respeito a apenas uma aula, e não ao perfil docente, definitivo e imutável do professor em questão. 
às ações docentes encontradas nas aulas de dois professores, por meio da articulação entre dois instrumentos utilizados para analisar a ação do professor.

Sendo assim, a partir dessa pesquisa que teve, desde a sua concepção, a intenção de se desenvolver no interior da sala de aula, concluímos que a ênfase nas ações desenvolvidas pelo professor em seu ambiente de trabalho pode contribuir para a pesquisa educacional, pois estamos de acordo com Charlot (2008, p.91), quando afirma que o papel da pesquisa educacional seria o de "forjar instrumentos, ferramentas para melhor entender o que está acontecendo na sala de aula; criar inteligibilidade para melhor entender o que está acontecendo ali’".

Dessa forma, a maneira com a qual organizamos e analisamos os dados pode vir a ser útil para que se possa realizar um movimento de pesquisa para diagnóstico e planejamento da ação docente nos estudos em formação de professores. Um meio de se trabalhar o tema, por exemplo, seria propor a um grupo de professores (de diversas áreas do conhecimento, em formação ou já em exercício) que identifique as categorias de ação docente encontradas em gravações de suas próprias aulas e as compare com as deste estudo. Além disso, também seria possível proporcionar a este grupo momentos de reflexão a respeito de quais setores da Matriz do Professor compreendem que precisariam enfatizar.

\section{AGRADECIMENTOS}

Agradecemos à Capes, ao CNPq e à Fundação Araucária, pelo apoio financeiro. Às orientadoras em Portugal, pelo trabalho em conjunto, carinho e solicitude, e à Escola portuguesa, por ter nos acolhido durante a coleta dos dados.

\section{REFERÊNCIAS}

ARRUDA, S. M.; LIMA, J. P. C.; PASSOS, M. M. Um novo instrumento para a análise da ação do professor em sala de aula. Revista Brasileira de Pesquisa em Educação em Ciências, [s. l.], v. 11, n. 2, p. 139-160, 2011.

ARRUDA, S. M; PASSOS, M. M. Instrumentos para a análise da relação com o saber em sala de aula. Revista de Produtos Educacionais e Pesquisas em Ensino, [s. l.], v. 1, n. 2, p. $95-$

$-115,2017$.

CHARLOT, B. Da relação com o saber: elementos para uma teoria. Porto Alegre: Artmed, 2000.

CHARLOT, B. Formação de professores: a pesquisa e a política educacional. In: PIMENTA, S. G.; GHEDIN, E. Professor reflexivo no Brasil: gênese e crítica de um conceito. São Paulo: Cortez, 2008.

CHEVALLARD, Y. La transposición didáctica: del saber sabio al saber enseñado. Buenos Aires: Aique Grupo Editor, 2005.

GAUTHIER, C.; MARTINEAU, S.; DESBIENS, J. F.; MALO, A.; SIMARD, D. Por uma teoria da Pedagogia: pesquisas contemporâneas sobre o saber docente. Ijuí: Unijuí, 2006.

MORAES, R.; GALIAZZI, M. C. Análise textual discursiva. Ijuí: Unijuí, 2011.

PASSOS M. M. O professor de matemática e sua formação: análise de três décadas da produção bibliográfica em periódicos na área de educação matemática no Brasil. 2009. Tese (Doutorado) Faculdade de Ciências, UNESP, Bauru, 2009.

PIRATELO, M. V. M. Um estudo sobre as ações docentes de professores e monitores em um ambiente integrado de $\mathbf{1}^{\mathrm{o}}$ ciclo em Portugal. Tese (Doutorado em Ensino de Ciências e Educação Matemática) - UEL, Londrina, 2018.

TARDIF, M. Saberes docentes e formação profissional. Petrópolis: Vozes, 2002. 
TARDIF, M.; LESSARD, C. O trabalho docente. Petrópolis: Vozes. 2008.

\section{APÊNDICE}

Descrição das categorias de ação docente, justificativa para a alocação nos setores da M(P).

\begin{tabular}{|c|c|c|c|c|}
\hline $\begin{array}{c}\text { Codificação } \\
\text { da ação } \\
\text { docente }\end{array}$ & $\begin{array}{l}\text { Categoria de } \\
\text { ação docente / } \\
\text { Setor da Matriz }\end{array}$ & $\begin{array}{l}\text { Descrição da } \\
\text { categoria de ação } \\
\text { docente }\end{array}$ & $\begin{array}{c}\text { Justificativa para alocação } \\
\text { nos setores da Matriz }\end{array}$ & $\begin{array}{l}\text { Exemplos de ações docentes } \\
\text { observadas em sala de aula }\end{array}$ \\
\hline 1. & $\begin{array}{c}\text { Atribuição de } \\
\text { atividades para a } \\
\text { aula: } 3 \mathrm{~A}\end{array}$ & $\begin{array}{l}\text { O professor atribui } \\
\text { tarefas a serem } \\
\text { realizadas no } \\
\text { ambiente de sala de } \\
\text { aula. }\end{array}$ & $\begin{array}{l}\text { 3A - Esta ação docente } \\
\text { possui relação com a } \\
\text { tentativa do professor de } \\
\text { fazer com que seus alunos } \\
\text { compreendam, por meio de } \\
\text { exercícios, o conteúdo } \\
\text { abordado. }\end{array}$ & $\begin{array}{l}\text { P2: P2 distribui as fichas à } \\
\text { classe. }\end{array}$ \\
\hline 2. & $\begin{array}{l}\text { Atribuição de } \\
\text { atividades para } \\
\text { casa: } 3 \mathrm{~A}\end{array}$ & $\begin{array}{l}\text { O professor atribui } \\
\text { tarefas para que os } \\
\text { alunos cumpram em } \\
\text { casa e entreguem ao } \\
\text { professor em uma } \\
\text { aula posterior. }\end{array}$ & $\begin{array}{l}\text { 3A - Tal ação docente diz } \\
\text { respeito à tentativa do } \\
\text { professor de fazer com que } \\
\text { seus alunos compreendam, } \\
\text { por meio de exercícios a } \\
\text { serem realizados em casa, o } \\
\text { conteúdo abordado. }\end{array}$ & $\begin{array}{l}\text { P1: Olha, hoje o trabalho de } \\
\text { casa é estudar. Ah, pois é. }\end{array}$ \\
\hline 3. & $\begin{array}{l}\text { Atribuição de } \\
\text { funções para } \\
\text { alguns alunos: } \\
\text { 2C }\end{array}$ & $\begin{array}{l}\text { O professor distribui } \\
\text { funções aos alunos } \\
\text { para a organização } \\
\text { do ambiente de sala } \\
\text { de aula. }\end{array}$ & $\begin{array}{l}\text { 2C - Esta ação docente } \\
\text { relaciona-se às negociações } \\
\text { de valores do professor } \\
\text { com seus alunos para o } \\
\text { andamento da aula. }\end{array}$ & $\begin{array}{l}\text { P2: E3, retire as fichas, faz um } \\
\text { favor. }\end{array}$ \\
\hline 4. & Aviso: 2C & $\begin{array}{l}\text { O professor repassa } \\
\text { recados referentes a } \\
\text { atividades e } \\
\text { procedimentos } \\
\text { requeridos pela } \\
\text { instituição de } \\
\text { ensino, a datas } \\
\text { relativas a feriados } \\
\text { etc. }\end{array}$ & $\begin{array}{l}2 \mathrm{C} \text { - Esta ação docente diz } \\
\text { respeito à comunicação, por } \\
\text { parte do professor, acerca } \\
\text { das atividades agendadas } \\
\text { pela instituição. }\end{array}$ & $\begin{array}{l}\text { P2: Vamos ter cá o professor } \\
\text { (nome do professor PO) que } \\
\text { vai assistir à aula, que é para ver } \\
\text { como é que a classe funciona, se } \\
\text { se portam bem para depois, nas } \\
\text { reuniões, poder dizer como é } \\
\text { que a classe funciona. }\end{array}$ \\
\hline 5. & $\begin{array}{l}\text { Chamada à } \\
\text { ordem/repre- } \\
\text { ensão: } 2 \mathrm{C}\end{array}$ & $\begin{array}{l}\text { O professor adverte } \\
\text { e repreende seus } \\
\text { alunos para que } \\
\text { apresentem atitudes } \\
\text { comportamentais } \\
\text { desejadas. }\end{array}$ & $\begin{array}{c}\mathrm{C}-\mathrm{Tal} \text { ação docente } \\
\text { refere-se às negociações de } \\
\text { valores do professor com } \\
\text { seus alunos para gerência } \\
\text { das atividades a serem } \\
\text { desenvolvidas. }\end{array}$ & $\begin{array}{c}\text { P1: Olha, vamos lá tomar } \\
\text { atenção. Há meninos que estão } \\
\text { a conversar. }\end{array}$ \\
\hline 6. & $\begin{array}{l}\text { Chamada de } \\
\text { atenção com } \\
\text { relação à } \\
\text { organização dos } \\
\text { materiais: 2A }\end{array}$ & $\begin{array}{l}\text { O professor } \\
\text { repreende o mau } \\
\text { uso de materiais que } \\
\text { estão sendo } \\
\text { utilizados pelos } \\
\text { alunos. }\end{array}$ & $\begin{array}{l}\text { 2A - Esta ação docente } \\
\text { relaciona-se com o modo } \\
\text { como o professor } \\
\text { compreende que o uso dos } \\
\text { materiais, por parte dos } \\
\text { alunos, pode influenciar em } \\
\text { seu ensino. }\end{array}$ & $\begin{array}{l}\text { P2: Vamos fazer os números } \\
\text { pequeninos para deixar espaço } \\
\text { para registrar o estado do } \\
\text { tempo. }\end{array}$ \\
\hline 7. & $\begin{array}{l}\text { Chamada de } \\
\text { atenção } \\
\text { relacionada ao } \\
\text { conteúdo: } 2 \mathrm{~A}\end{array}$ & $\begin{array}{l}\text { O professor requer } \\
\text { atenção dos alunos } \\
\text { para os conteúdos e } \\
\text { atividades que estão } \\
\text { sendo realizadas } \\
\text { durante a aula. }\end{array}$ & $\begin{array}{l}\text { 2A - Esta ação docente diz } \\
\text { respeito à compreensão do } \\
\text { professor acerca da } \\
\text { concentração de seus alunos } \\
\text { quanto às atividades que } \\
\text { desenvolve. }\end{array}$ & $\begin{array}{l}\text { P1: Mas ele não estava atento. É } \\
\text { o que dá quem não estava } \\
\text { atento, depois tem mais } \\
\text { trabalho. Mas ele não esteve } \\
\text { atento, não esteve com atenção. } \\
\text { Eu, se calhar, vou perguntar a } \\
\text { outro menino que também não } \\
\text { esteve com atenção. }\end{array}$ \\
\hline 8. & $\begin{array}{l}\text { Chamado para } \\
\text { um aluno ir ao }\end{array}$ & $\begin{array}{l}\text { O professor solicita } \\
\text { que um aluno }\end{array}$ & $\begin{array}{l}\text { 3A - Esta ação docente } \\
\text { relaciona-se com a }\end{array}$ & $\begin{array}{l}\text { P1: Então venha o E13 aqui } \\
\text { explicar. }\end{array}$ \\
\hline
\end{tabular}

Educação em Revista|Belo Horizonte|v.36|e222681|2020 


\begin{tabular}{|c|c|c|c|c|}
\hline & quadro: $3 \mathrm{~A}$ & $\begin{array}{l}\text { explique aos demais } \\
\text { alunos a solução de } \\
\text { um exercício ou } \\
\text { atividade no quadro. }\end{array}$ & $\begin{array}{l}\text { compreensão do professor } \\
\text { quanto à prática do aluno } \\
\text { para consolidar seu } \\
\text { aprendizado. }\end{array}$ & \\
\hline 9. & $\begin{array}{l}\text { Comunicação } \\
\text { oral de conteúdo } \\
\text { presente no } \\
\text { quadro ou livro } \\
\text { didático: } 2 \mathrm{~A}\end{array}$ & $\begin{array}{l}\text { O professor realiza a } \\
\text { leitura de um } \\
\text { conteúdo presente } \\
\text { no quadro ou no } \\
\text { livro didático dos } \\
\text { alunos. }\end{array}$ & $\begin{array}{l}2 \mathrm{~A} \text { - Esta ação docente } \\
\text { refere-se à compreensão do } \\
\text { professor acerca do seu } \\
\text { ensino por meio da leitura } \\
\text { do material didático. }\end{array}$ & $\begin{array}{l}\text { P2: Vocês têm a vossa ficha. } \\
\text { Então tem a vossa fichinha de } \\
\text { matemática que diz assim: na } \\
\text { escola todos os dias foi } \\
\text { assinalado os estados do tempo } \\
\text { no calendário. Copie para o } \\
\text { mapa a seguir e lá observe o } \\
\text { registro desse mês. }\end{array}$ \\
\hline 10. & $\begin{array}{l}\text { Correção dos } \\
\text { exercícios no } \\
\text { quadro: } 2 \mathrm{~A}\end{array}$ & $\begin{array}{l}\text { O professor realiza a } \\
\text { correção dos } \\
\text { exercícios e } \\
\text { atividades propostas } \\
\text { no quadro. } \\
\end{array}$ & $\begin{array}{c}\text { 2A - Esta ação docente } \\
\text { possui relação com objetos } \\
\text { e como eles podem auxiliar } \\
\text { no ato de ensinar }\end{array}$ & $\begin{array}{l}\text { P1: P1 vai até o quadro e E20 } \\
\text { vai também. }\end{array}$ \\
\hline 11. & Correção: $2 \mathrm{~A}$ & $\begin{array}{l}\text { O professor corrige } \\
\text { verbalmente as } \\
\text { respostas que } \\
\text { considera } \\
\text { equivocadas de seus } \\
\text { alunos. }\end{array}$ & $\begin{array}{l}2 \mathrm{~A} \text { - Tal ação docente diz } \\
\text { respeito à utilização do } \\
\text { conhecimento do professor } \\
\text { para corrigir práticas e } \\
\text { compreensões errôneas dos } \\
\text { alunos. }\end{array}$ & $\begin{array}{l}\text { P1: Essa aí não pode ser a } \\
\text { resposta. }\end{array}$ \\
\hline 12. & Elogio: 3B & $\begin{array}{l}\text { O professor elogia, } \\
\text { expressa entusiasmo, } \\
\text { carinho ou afeição } \\
\text { (verbalmente) frente } \\
\text { ao comportamento } \\
\text { ou resposta que } \\
\text { considera adequada. }\end{array}$ & $\begin{array}{l}\text { 3B - Esta ação tem relação } \\
\text { com o quanto o professor } \\
\text { gosta e como avalia a } \\
\text { aprendizagem de seus } \\
\text { alunos. }\end{array}$ & $\begin{array}{l}\text { P2: Boa, muito bem! Linda } \\
\text { menina! }\end{array}$ \\
\hline 13. & $\begin{array}{l}\text { Escrita no } \\
\text { quadro: } 2 \mathrm{~A}\end{array}$ & $\begin{array}{l}\text { O professor expõe } \\
\text { na lousa o conteúdo } \\
\text { que deseja abordar. }\end{array}$ & $\begin{array}{c}2 \mathrm{~A} \text { - Tal ação refere-se à } \\
\text { interação do professor com } \\
\text { o quadro para promover } \\
\text { seu ensino. }\end{array}$ & P1: P1 escreve: $3,627 \times 10=$ \\
\hline 14. & Explicação: $2 \mathrm{~A}$ & $\begin{array}{l}\text { O professor explica } \\
\text { o conteúdo da aula, } \\
\text { a resposta dos } \\
\text { exercícios, as } \\
\text { atividades ou } \\
\text { questionamentos } \\
\text { dos alunos. }\end{array}$ & $\begin{array}{l}\text { 2A - Esta ação refere-se à } \\
\text { busca do professor por } \\
\text { ensinar um conteúdo } \\
\text { disciplinar pertencente ao } \\
\text { currículo previamente } \\
\text { estabelecido pela instituição } \\
\text { ou pertinente à aula. }\end{array}$ & $\begin{array}{l}\text { P1: Quando nós multiplicamos } \\
\text { por dez andamos uma casa para } \\
\text { frente, quando multiplicamos } \\
\text { por cem andamos duas, e } \\
\text { quando multiplicamos por mil } \\
\text { andamos três. }\end{array}$ \\
\hline 15. & $\begin{array}{l}\text { Gesto de afeto: } \\
\text { 2B }\end{array}$ & $\begin{array}{c}\text { O professor } \\
\text { expressa afeto e } \\
\text { carinho } \\
\text { gestualmente (por } \\
\text { meio de um abraço, } \\
\text { por exemplo). }\end{array}$ & $\begin{array}{c}\text { 2B - Esta ação refere-se às } \\
\text { demonstrações de emoções } \\
\text { dos professores dirigidas } \\
\text { aos alunos sem a } \\
\text { necessidade de serem } \\
\text { avaliativas quanto aos } \\
\text { acertos dos alunos. }\end{array}$ & P2: P2 faz carinho em E17. \\
\hline 16. & Imposição: $2 \mathrm{~A}$ & $\begin{array}{l}\text { O professor dita } \\
\text { regras relativas às } \\
\text { atividades } \\
\text { ministradas que } \\
\text { deseja que sejam } \\
\text { cumpridas. }\end{array}$ & $\begin{array}{c}\text { 2A - Esta ação refere-se a } \\
\text { como o professor impõe } \\
\text { sua forma de ensino do } \\
\text { conteúdo para atingir os } \\
\text { objetivos que propôs para a } \\
\text { aula. }\end{array}$ & $\begin{array}{l}\text { P2: Olha, eu quero isto tudo de } \\
\text { cálculo mental. }\end{array}$ \\
\hline 17. & $\begin{array}{l}\text { Incentivo à } \\
\text { interação entre } \\
\text { os alunos: } 3 \mathrm{~A}\end{array}$ & $\begin{array}{c}\text { O professor } \\
\text { incentiva um aluno a } \\
\text { explicar a sua forma } \\
\text { de resolver os } \\
\text { exercícios e } \\
\text { atividades para os } \\
\text { outros alunos. }\end{array}$ & $\begin{array}{l}\text { 3A - Esta ação possui } \\
\text { relação com a tentativa do } \\
\text { professor de incentivar seus } \\
\text { alunos a se comunicarem } \\
\text { visando seu aprendizado. }\end{array}$ & $\begin{array}{l}\text { P1: E2, então explica lá aos teus } \\
\text { colegas o que fizeste. }\end{array}$ \\
\hline 18. & Incentivo à & O professor & 3A - Esta ação relaciona- & P2: Diga mais, A16. \\
\hline
\end{tabular}

Educação em Revista|Belo Horizonte|v.36|e222681|2020 


\begin{tabular}{|c|c|c|c|c|}
\hline & $\begin{array}{l}\text { resposta de um } \\
\text { aluno: } 3 \mathrm{~A}\end{array}$ & $\begin{array}{l}\text { incentiva a } \\
\text { participação de um } \\
\text { dos alunos durante } \\
\text { sua aula. }\end{array}$ & $\begin{array}{l}\text {-se com a tentativa do } \\
\text { professor de incentivar um } \\
\text { aluno a aprender e se } \\
\text { envolver com as atividades } \\
\text { propostas. }\end{array}$ & \\
\hline 19. & $\begin{array}{l}\text { Incentivo à } \\
\text { resposta dos } \\
\text { alunos: } 3 \mathrm{~A}\end{array}$ & $\begin{array}{c}\text { O professor } \\
\text { incentiva a } \\
\text { participação dos } \\
\text { alunos durante a sua } \\
\text { aula. }\end{array}$ & $\begin{array}{l}\text { 3A - Esta ação relaciona- } \\
\text {-se com a tentativa do } \\
\text { professor de incentivar seus } \\
\text { alunos a aprenderem e se } \\
\text { envolverem com as } \\
\text { atividades propostas. }\end{array}$ & $\begin{array}{l}\text { P1: E2 vai explicar o que fez, } \\
\text { onde é que estava a vírgula e } \\
\text { como é que teve que fazer para } \\
\text { ficar o resultado correto. }\end{array}$ \\
\hline 20. & Incentivo: 3B & $\begin{array}{l}\text { O professor dirige } \\
\text { palavras de conforto } \\
\text { e incentivo para que } \\
\text { seus alunos } \\
\text { participem de suas } \\
\text { aulas sem receio de } \\
\text { cometer erros. }\end{array}$ & $\begin{array}{l}\text { 3B - Tal ação tem relação } \\
\text { com a busca do professor } \\
\text { em incutir o gosto pelo } \\
\text { conteúdo no aluno, } \\
\text { promovendo uma sensação } \\
\text { de conforto para constituir } \\
\text { seu aprendizado. }\end{array}$ & $\begin{array}{c}\text { P1: Olha, é assim. Nós não } \\
\text { aprendemos só com as coisas } \\
\text { certas, também aprendemos } \\
\text { quando erramos. Olha aqui, não } \\
\text { quero essa história de tenho } \\
\text { medo de estar errado não, } \\
\text { porque mesmo que esteja } \\
\text { errado nós temos que tentar, ou } \\
\text { não? }\end{array}$ \\
\hline 21. & $\begin{array}{l}\text { Indicação com } \\
\text { as mãos: } 2 \mathrm{~A}\end{array}$ & $\begin{array}{l}\text { O professor aponta } \\
\text { com as mãos (ou } \\
\text { somente com o } \\
\text { dedo) para um } \\
\text { ponto específico da } \\
\text { lousa o que quer que } \\
\text { os alunos prestem } \\
\text { atenção. }\end{array}$ & $\begin{array}{c}\text { 2A - Esta ação diz respeito } \\
\text { ao uso das mãos como } \\
\text { ferramentas corporais que o } \\
\text { professor utiliza para } \\
\text { destacar o conteúdo que } \\
\text { considera mais relevante. }\end{array}$ & $\begin{array}{c}\text { P2: P2 aponta, no quadro } \\
\text { interativo, para as coordenadas } \\
\text { do gráfico. }\end{array}$ \\
\hline 22. & Instrução: 2A & $\begin{array}{l}\text { O professor instrui } \\
\text { seus alunos quanto à } \\
\text { utilização dos } \\
\text { materiais disponíveis } \\
\text { em sala de aula. }\end{array}$ & $\begin{array}{l}\text { 2A - Tal ação refere-se às } \\
\text { formas com as quais o } \\
\text { professor utiliza-se do } \\
\text { ensino para instruir seus } \\
\text { alunos na utilização de } \\
\text { cadernos, livros etc. }\end{array}$ & $\begin{array}{c}\text { P2: Olha, podem colocar a data } \\
\text { no livro de matemática. No } \\
\text { livro não, no caderno de } \\
\text { matemática. }\end{array}$ \\
\hline 23. & $\begin{array}{l}\text { Interação com } \\
\text { os alunos: } 3 \mathrm{~B}\end{array}$ & $\begin{array}{l}\text { O professor interage } \\
\text { com seus alunos } \\
\text { perguntando-lhes a } \\
\text { respeito de assuntos } \\
\text { relacionados ao dia a } \\
\text { dia. }\end{array}$ & $\begin{array}{l}\text { 3B - Esta ação diz respeito } \\
\text { ao envolvimento do } \\
\text { professor com seus alunos. }\end{array}$ & $\begin{array}{l}\text { P1: É. E então E17, já tens } \\
\text { óculos novos? }\end{array}$ \\
\hline 24. & $\begin{array}{l}\text { Interação com } \\
\text { outros } \\
\text { professores: } 2 \mathrm{C}\end{array}$ & $\begin{array}{c}\text { O professor } \\
\text { conversa com outros } \\
\text { professores } \\
\text { presentes em sala de } \\
\text { aula. }\end{array}$ & $\begin{array}{c}\text { 2C - Esta ação possui } \\
\text { relação com as negociações } \\
\text { de valores e comunicação } \\
\text { entre os professores } \\
\text { presentes na aula. }\end{array}$ & $\begin{array}{l}\text { P2: P2 conversa com outro } \\
\text { professor a respeito de uma } \\
\text { aluna de outra turma. }\end{array}$ \\
\hline 25. & $\begin{array}{l}\text { Introdução de } \\
\text { um problema: } \\
2 \mathrm{~A}\end{array}$ & $\begin{array}{l}\text { O professor utiliza- } \\
\text {-se de uma situação- } \\
\text {-problema para } \\
\text { introduzir sua } \\
\text { abordagem. }\end{array}$ & $\begin{array}{l}\text { 2A - Esta ação docente diz } \\
\text { respeito à forma de ensino } \\
\text { com a qual o professor } \\
\text { introduz um conteúdo, na } \\
\text { forma de um problema a } \\
\text { ser resolvido na aula. }\end{array}$ & $\begin{array}{l}\text { P1: Eu tenho ali dois meninos a } \\
\text { conversar e vamos ver o que } \\
\text { eles estão a conversar. [...] Este } \\
\text { menino do chapéu vermelho diz } \\
\text { assim: Quando é que obtemos } \\
\text { um produto maior, } \\
\text { multiplicando um número por } \\
\text { dez ou por uma décima? }\end{array}$ \\
\hline 26. & $\begin{array}{l}\text { Ordem para a } \\
\text { organização de } \\
\text { sala de aula: } 2 \mathrm{C}\end{array}$ & $\begin{array}{l}\text { O professor emite } \\
\text { uma ordem a seus } \\
\text { alunos relacionada a } \\
\text { elementos faltantes } \\
\text { para a explicação do } \\
\text { conteúdo (objetos } \\
\text { como um giz, uma } \\
\text { caneta a tinta etc.). }\end{array}$ & $\begin{array}{l}\text { 2C - Tal ação refere-se à } \\
\text { manutenção de um } \\
\text { ambiente propício para o } \\
\text { desenvolvimento da aula. }\end{array}$ & $\begin{array}{l}\text { P1: Ora, enquanto eu estou a } \\
\text { apagar o quadro, o E5, isso não } \\
\text { está a escrever nada bem, vai lá } \\
\text { pedir um outro marcador, faz } \\
\text { um favor. (Professora pede para } \\
\text { que um aluno busque uma nova } \\
\text { caneta.) }\end{array}$ \\
\hline 27. & Parecer/retorno: & O professor expõe & 2A - Esta ação possui & P1: Tivemos que acrescentar \\
\hline
\end{tabular}

Educação em Revista|Belo Horizonte|v.36|e222681|2020 


\begin{tabular}{|c|c|c|c|c|}
\hline & $2 \mathrm{~A}$ & $\begin{array}{l}\text { um parecer a } \\
\text { respeito de uma } \\
\text { resposta ou fala de } \\
\text { um aluno. }\end{array}$ & $\begin{array}{l}\text { relação com os métodos de } \\
\text { ensino que o professor } \\
\text { utiliza para emitir pareceres } \\
\text { quanto às respostas dos } \\
\text { alunos para perguntas e } \\
\text { exercícios propostos. }\end{array}$ & $\begin{array}{l}\text { um zero para andarmos para } \\
\text { trás, exatamente! }\end{array}$ \\
\hline 28. & $\begin{array}{l}\text { Percepção do } \\
\text { próprio erro: } 2 \mathrm{~A}\end{array}$ & $\begin{array}{l}\text { O professor percebe } \\
\text { que agiu } \\
\text { equivocadamente e } \\
\text { reage na busca por } \\
\text { corrigir seu erro. }\end{array}$ & $\begin{array}{l}\text { 2A - Esta ação diz respeito } \\
\text { à compreensão do } \\
\text { professor quanto aos erros } \\
\text { que cometeu em seu ato de } \\
\text { ensinar. }\end{array}$ & $\begin{array}{c}\text { P2: Eu me enganei. (P2 } \\
\text { escreveu a data errada no } \\
\text { quadro.) }\end{array}$ \\
\hline 29. & $\begin{array}{l}\text { Pergunta com } \\
\text { duas } \\
\text { possibilidades de } \\
\text { resposta para a } \\
\text { classe: } 3 \mathrm{~A}\end{array}$ & $\begin{array}{l}\text { O professor dirige a } \\
\text { todos os alunos uma } \\
\text { pergunta que só } \\
\text { pode ser respondida } \\
\text { com sim ou não, } \\
\text { certo ou errado etc. }\end{array}$ & $\begin{array}{l}\text { 3A - Esta ação refere-se à } \\
\text { tentativa do professor em } \\
\text { envolver os alunos em um } \\
\text { diálogo que procura } \\
\text { estabelecer durante a aula. }\end{array}$ & P1: É ou não é? \\
\hline 30. & $\begin{array}{l}\text { Pergunta com } \\
\text { duas } \\
\text { possibilidades de } \\
\text { resposta para um } \\
\text { aluno: } 3 \mathrm{~A}\end{array}$ & $\begin{array}{l}\text { O professor } \\
\text { direciona a um aluno } \\
\text { uma pergunta que só } \\
\text { pode ser respondida } \\
\text { com sim ou não, } \\
\text { certo ou errado etc. }\end{array}$ & $\begin{array}{l}\text { 3A - Esta ação refere-se à } \\
\text { tentativa do professor em } \\
\text { envolver um aluno em um } \\
\text { diálogo que procura } \\
\text { estabelecer durante a aula. }\end{array}$ & $\begin{array}{l}\text { P1: Acrescentastes os zeros } \\
\text { necessários, não foi? }\end{array}$ \\
\hline 31. & $\begin{array}{l}\text { Pergunta de } \\
\text { complementa- } \\
\text { ridade para a } \\
\text { classe: } 3 \mathrm{~A}\end{array}$ & $\begin{array}{l}\text { O professor dirige a } \\
\text { todos os alunos uma } \\
\text { pergunta que } \\
\text { termina com parte } \\
\text { da resposta para que } \\
\text { respondam } \\
\text { exatamente o que } \\
\text { querem. }\end{array}$ & $\begin{array}{l}3 \mathrm{~A} \text { - Esta ação docente } \\
\text { refere-se à busca do } \\
\text { professor em suscitar a } \\
\text { resposta dos alunos para } \\
\text { suas perguntas. }\end{array}$ & $\begin{array}{c}\text { P1: Nós já vimos que quando } \\
\text { multiplicamos por uma décima } \\
\text { nós deslocamos uma casa para } \\
\text { a...? }\end{array}$ \\
\hline 32. & $\begin{array}{l}\text { Pergunta de } \\
\text { complementa- } \\
\text { ridade para um } \\
\text { aluno: } 3 \mathrm{~A}\end{array}$ & $\begin{array}{c}\text { O professor } \\
\text { direciona a um aluno } \\
\text { uma pergunta que } \\
\text { termina com parte } \\
\text { da resposta para que } \\
\text { responda } \\
\text { exatamente o que } \\
\text { quer. }\end{array}$ & $\begin{array}{l}\text { 3A - Esta ação refere-se à } \\
\text { busca do professor em } \\
\text { suscitar a resposta de um } \\
\text { aluno para suas perguntas. }\end{array}$ & $\begin{array}{l}\text { P1: Três unidades e seiscentos e } \\
\text { vinte e sete mil é...? } \\
\text { (milésimas). }\end{array}$ \\
\hline 33. & $\begin{array}{l}\text { Pergunta de } \\
\text { organização de } \\
\text { sala de aula: } 2 \mathrm{~A}\end{array}$ & $\begin{array}{l}\text { O professor realiza } \\
\text { essas perguntas para } \\
\text { organizar suas aulas, } \\
\text { e planejar ações } \\
\text { futuras. }\end{array}$ & $\begin{array}{l}\text { 2A - Esta ação refere-se a } \\
\text { uma pergunta para tomada } \\
\text { de decisão quanto à } \\
\text { gerência do conteúdo a ser } \\
\text { ministrado na aula. }\end{array}$ & $\begin{array}{l}\text { P1: Espera só um bocadinho. } \\
\text { Não posso apagar o quadro? }\end{array}$ \\
\hline 34. & $\begin{array}{l}\text { Pergunta que } \\
\text { conduz ao } \\
\text { raciocínio para a } \\
\text { classe: } 3 \mathrm{~A}\end{array}$ & $\begin{array}{l}\text { O professor dirige a } \\
\text { todos os alunos uma } \\
\text { pergunta que } \\
\text { realmente os façam } \\
\text { pensar e refletir a } \\
\text { respeito do } \\
\text { conteúdo, além } \\
\text { disso, atribui um } \\
\text { tempo para que } \\
\text { possam responder. }\end{array}$ & $\begin{array}{l}\text { 3A - Esta ação refere-se à } \\
\text { busca do professor em } \\
\text { suscitar a reflexão dos } \\
\text { alunos e resposta dos } \\
\text { mesmos para a } \\
\text { consolidação do conteúdo } \\
\text { ministrado. }\end{array}$ & $\begin{array}{l}\text { P1: Então, quando é que } \\
\text { obtemos um número maior, } \\
\text { quando multiplicamos por dez } \\
\text { ou quando multiplicamos por } \\
\text { uma décima? }\end{array}$ \\
\hline 35. & $\begin{array}{l}\text { Pergunta que } \\
\text { conduz ao } \\
\text { raciocínio para } \\
\text { um aluno: } 3 \mathrm{~A}\end{array}$ & $\begin{array}{c}\text { O professor } \\
\text { direciona a um dos } \\
\text { alunos uma pergunta } \\
\text { que realmente o faça } \\
\text { pensar e refletir a } \\
\text { respeito do } \\
\text { conteúdo; além } \\
\text { disso, atribui um }\end{array}$ & $\begin{array}{l}\text { 3A - Esta ação refere-se à } \\
\text { busca do professor em } \\
\text { suscitar a reflexão de um } \\
\text { aluno e resposta do mesmo } \\
\text { para a consolidação do } \\
\text { conteúdo ministrado. }\end{array}$ & $\begin{array}{l}\text { P2: A3, como é que começamos } \\
\text { a fazer a contagem do tempo? }\end{array}$ \\
\hline
\end{tabular}

Educação em Revista|Belo Horizonte|v.36|e222681|2020 


\begin{tabular}{|c|c|c|c|c|}
\hline & & $\begin{array}{l}\text { tempo para que } \\
\text { possa responder. }\end{array}$ & & \\
\hline 36. & $\begin{array}{l}\text { Pergunta } \\
\text { retórica: } 2 \mathrm{~A}\end{array}$ & $\begin{array}{c}\text { O professor } \\
\text { responde à sua } \\
\text { própria pergunta que } \\
\text { utilizou para dar } \\
\text { continuidade à sua } \\
\text { linha de raciocínio } \\
\text { ou explicação. }\end{array}$ & $\begin{array}{l}\text { 2A - Esta ação diz respeito } \\
\text { à utilização de uma } \\
\text { pergunta como ferramenta } \\
\text { para o ensino de um } \\
\text { conteúdo disciplinar. }\end{array}$ & P1: Por dez, não é? \\
\hline 37. & $\begin{array}{l}\text { Pergunta sem } \\
\text { sentido: } 2 \mathrm{~A}\end{array}$ & $\begin{array}{c}\text { O professor } \\
\text { questiona seus } \\
\text { alunos a respeito do } \\
\text { término de } \\
\text { atividades propostas. }\end{array}$ & $\begin{array}{c}\text { 2A - Esta ação refere-se à } \\
\text { busca do professor em } \\
\text { saber se os seus alunos } \\
\text { completaram as tarefas } \\
\text { atribuídas por ele. }\end{array}$ & P2: Já fez as contas? \\
\hline 38. & $\begin{array}{l}\text { Pergunta sem } \\
\text { sentido: } 2 \mathrm{C}\end{array}$ & $\begin{array}{c}\text { O professor } \\
\text { questiona quais os } \\
\text { alunos responsáveis } \\
\text { por mau } \\
\text { comportamento. }\end{array}$ & $\begin{array}{l}\text { 2C - Esta ação refere-se à } \\
\text { busca do professor em } \\
\text { saber quais alunos estão } \\
\text { atrapalhando o } \\
\text { desenvolvimento da aula. }\end{array}$ & $\begin{array}{c}\text { P2: Quem estava a falar, a falar } \\
\text { e a falar? }\end{array}$ \\
\hline 39. & $\begin{array}{l}\text { Pergunta sem } \\
\text { sentido: } 3 \mathrm{~A}\end{array}$ & $\begin{array}{c}\text { O professor } \\
\text { questiona a seus } \\
\text { alunos se possuem } \\
\text { dúvidas quanto ao } \\
\text { conteúdo abordado. }\end{array}$ & $\begin{array}{l}\text { 3A - Esta ação refere-se à } \\
\text { busca do professor em } \\
\text { saber se os seus alunos } \\
\text { ainda possuem dúvidas a } \\
\text { respeito do conteúdo } \\
\text { ministrado. }\end{array}$ & P1: Alguma dúvida? \\
\hline 40. & $\begin{array}{l}\text { Pergunta sem } \\
\text { sentido: } 3 \mathrm{C}\end{array}$ & $\begin{array}{c}\text { O professor } \\
\text { confronta seus } \\
\text { alunos a respeito de } \\
\text { respostas que } \\
\text { oferecem, baseados } \\
\text { em pareceres e } \\
\text { atitudes de outros } \\
\text { alunos. }\end{array}$ & $\begin{array}{l}\text { 3C - Esta ação refere-se às } \\
\text { formas com as quais o } \\
\text { professor questiona seus } \\
\text { alunos acerca das maneiras } \\
\text { em que eles se comunicam } \\
\text { entre si. }\end{array}$ & $\begin{array}{l}\text { P2: Então, por a A5 estar ao } \\
\text { contrário está certo? }\end{array}$ \\
\hline 41. & Permissão: 2C & $\begin{array}{l}\text { O professor concede } \\
\text { uma permissão para } \\
\text { que o aluno realize } \\
\text { necessidades } \\
\text { fisiológicas ou } \\
\text { quebre } \\
\text { temporariamente } \\
\text { alguma regra } \\
\text { instituída (andar pela } \\
\text { sala, por exemplo). }\end{array}$ & $\begin{array}{c}\text { 2C - Esta ação expressa o } \\
\text { poder concentrado na } \\
\text { figura do professor } \\
\text { (concedido pela instituição } \\
\text { em que trabalha), que } \\
\text { decide por permitir ações } \\
\text { dos alunos. }\end{array}$ & $\begin{array}{l}\text { P1: Vai lá em um instante (ao } \\
\text { banheiro). }\end{array}$ \\
\hline 42. & Punição: 2C & $\begin{array}{l}\text { O professor aplica } \\
\text { algum tipo de } \\
\text { punição, devido a } \\
\text { um comportamento } \\
\text { não desejado. }\end{array}$ & $\begin{array}{c}\text { 2C - Esta ação expressa o } \\
\text { poder concentrado na } \\
\text { figura do professor } \\
\text { (concedido pela instituição } \\
\text { em que atua), que decide } \\
\text { por punir os alunos. }\end{array}$ & $\begin{array}{c}\text { P2: O E11, abaixa lá a } \\
\text { cabecinha, faz um favor. }{ }^{18}\end{array}$ \\
\hline 43. & $\begin{array}{l}\text { Recolha de } \\
\text { atividades: } 2 \mathrm{~A}\end{array}$ & $\begin{array}{c}\text { O professor recolhe } \\
\text { as atividades dos } \\
\text { alunos para } \\
\text { posterior avaliação. }\end{array}$ & $\begin{array}{c}\text { 2A - Esta ação diz respeito } \\
\text { a uma ferramenta que o } \\
\text { professor se utiliza para } \\
\text { avaliar o seu ensino e a } \\
\text { aprendizagem dos seus } \\
\text { alunos. }\end{array}$ & $\begin{array}{l}\text { P1: P1 recebe trabalhos de } \\
\text { alguns alunos. }\end{array}$ \\
\hline 44. & $\begin{array}{l}\text { Retrospecto da } \\
\text { aula: } 2 \mathrm{~A}\end{array}$ & $\begin{array}{l}\text { O professor realiza } \\
\text { um retrospecto da } \\
\text { aula, enfatizando os }\end{array}$ & $\begin{array}{l}2 \mathrm{~A} \text { - Esta ação refere-se a } \\
\text { um artifício argumentativo } \\
\text { em que o professor se }\end{array}$ & $\begin{array}{l}\text { P1: Nós agora só estivemos a } \\
\text { multiplicar por dez, por cem e } \\
\text { por mil. }\end{array}$ \\
\hline
\end{tabular}

${ }^{18}$ Fazer com que o aluno fique com a cabeça baixa encostada na carteira era uma das formas de os professores punirem seus alunos pelo mau comportamento apresentado.

Educação em Revista|Belo Horizonte|v.36|e222681|2020 


\begin{tabular}{|c|c|c|c|c|}
\hline & & $\begin{array}{l}\text { pontos que deseja } \\
\text { atribuir destaque. }\end{array}$ & $\begin{array}{c}\text { utiliza para relembrar e } \\
\text { sintetizar aspectos que } \\
\text { considera relevantes em sua } \\
\text { aula. }\end{array}$ & \\
\hline 45. & $\begin{array}{l}\text { Retrospecto de } \\
\text { aulas anteriores: } \\
2 \mathrm{~A}\end{array}$ & $\begin{array}{l}\text { O professor realiza } \\
\text { um retrospecto de } \\
\text { aulas anteriores, } \\
\text { enfatizando os } \\
\text { pontos que deseja } \\
\text { atribuir destaque. }\end{array}$ & $\begin{array}{c}\text { 2A - Esta ação refere-se a } \\
\text { um artifício argumentativo } \\
\text { em que o professor se } \\
\text { utiliza para relembrar e } \\
\text { sintetizar aspectos que } \\
\text { considera relevantes em } \\
\text { suas aulas anteriores. }\end{array}$ & $\begin{array}{l}\text { P2: Se vocês bem se lembram, } \\
\text { essa foi a ficha que fizemos, } \\
\text { registramos com a ajuda do E3 } \\
\text { que fez uns registros. }\end{array}$ \\
\hline 46. & $\begin{array}{l}\text { Supervisão/cor- } \\
\text { reção dos } \\
\text { exercícios: } 2 \mathrm{~A}\end{array}$ & $\begin{array}{c}\text { O professor } \\
\text { supervisiona as } \\
\text { atividades dos } \\
\text { alunos, andando pela } \\
\text { sala e emitindo } \\
\text { pareceres a respeito } \\
\text { do que fazem. }\end{array}$ & $\begin{array}{l}\text { 2A - Tal ação corresponde } \\
\text { a uma prática de ensino, na } \\
\text { qual o professor se utiliza } \\
\text { para corrigir os alunos e } \\
\text { ensinar o conteúdo } \\
\text { referente à aula. }\end{array}$ & $\begin{array}{c}\text { P1: P1 caminha entre as } \\
\text { carteiras e olha os exercícios } \\
\text { que os alunos fazem. }\end{array}$ \\
\hline 47. & $\begin{array}{l}\text { Utilização de } \\
\text { tecnologias para } \\
\text { o ensino: } 2 \mathrm{~A}\end{array}$ & $\begin{array}{l}\text { O professor utiliza- } \\
\text {-se de equipamentos } \\
\text { para desenvolver seu } \\
\text { ensino. }\end{array}$ & $\begin{array}{l}2 \mathrm{~A} \text { - Tal ação possui } \\
\text { relação com a utilização de } \\
\text { ferramentas tecnológicas } \\
\text { para promover o ensino. }\end{array}$ & P2: P2 liga o quadro interativo. \\
\hline
\end{tabular}

Fonte: os autores

Submetido: $24 / 04 / 2019$

Aprovado: 17/10/2019 